\title{
ALTERAÇŌES QUIMICAS E MINERALÓGICAS DE ANFIBOLITOS SOB CONDIÇÕES DE DRENAGEM DEFICIENTE (PRÉ-CAMBRIANO, S.P.)
}

ADEMÉRICO ANTONIO PACCOLA

Orientador: ANTONIO CARLOS DE TEIXEIRA MENDES

Dissertação apresentada a Escola Superior de Agricultura «LUIZ DE QUEIROZ» da Uni. versidade de São Paulo, para obtenção do título de Mestre em Solos e Nutrição de Plantas.

P I R A C I C A B A

Estado de São Paulo - Brasil

Julho, 1980 
.ii.

Que variedade,

Senhor, nas tuas obras!

Todas com sabedoria as fizestes; cheia está a terra das tuas riquezas.

Salmo $104: 24$ 
.iii.

A MARILENE, AOS MEUS PAIS E AO MEU FILHO QUE VIRA, DEDICO 
Ao Prof. ANTONIO CARLOS TEIXEIRA MENDES, pela orien tação na execução deste trabalho.

Ao Prof. CARLOS ROBERTO ESPINDOLA, pela colaboração e sugestões na redação, ao Prof. EBERARD WERNICK pelo auxílio na interpretação das secções delgadas e ao Prof. ANDRE MARTIN LOUIS NEPTUNE pela palavras de estímulo.

Ao INSTITUTO AGRONOMICO DE CAMPINAS, pela permissão para execução das análises de difração de Raios-X e ao INSTITU TO BRASILEIRO DE PESQUISAS TECNOLOGICAS DO PARANA pela cessão do equipamento para execução das análises de fluorescência de Raios-X.

Aos Senhores Francisco Martins Filho, Adalberto Fran cisco dos Santos e Joel Campos dos Santos, pela dedicação na execução dos desenhos e datilografia e, a todos os demais cole gas que de forma indireta nos auxiliaram na execução deste tra balho.

EM ESPECIAL

Ao Prof. JOSE ELIAS DE PAIVA NETTO, que com carinho e dedicação guiou nossos primeiros passos no caminho da pesqui sa, propôs-nos a execução deste trabalho, dando sugestões e so luções na metodologia e, acima de tudo amigo e grande compa nheiro de trabalho e a Faculdade de Ciências Agronômicas de Bo tucatu - UNESP que possibilitou a execução da maior parte des ta pesquisa. 
INDICE

Pag.

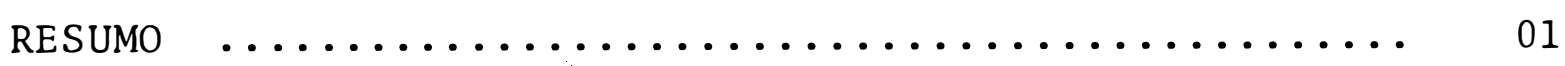

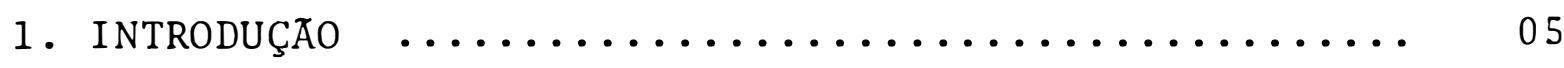

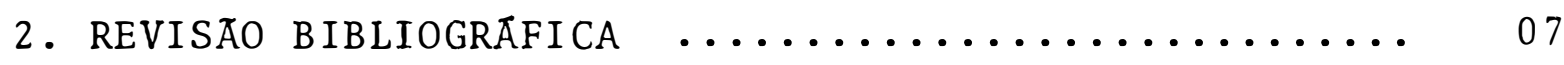

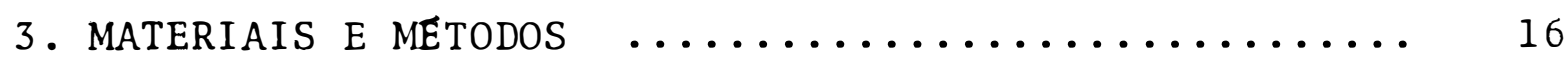

3.1. Material $\ldots \ldots \ldots \ldots \ldots \ldots \ldots \ldots \ldots \ldots \ldots \ldots \ldots$

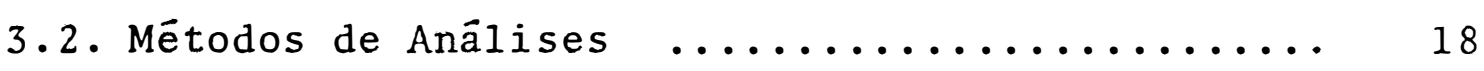

3.2.1. Separação das fraçōes granulomētricas .. 18

3.2.2. Difração de raios $-X \ldots \ldots \ldots \ldots \ldots \ldots$

3.2.3. Microscopia de polarização .......... 19

3.2.4. Análises químicas quantitativas ...... 19

3.2.5. Reação com ferrocianeto de potássio e

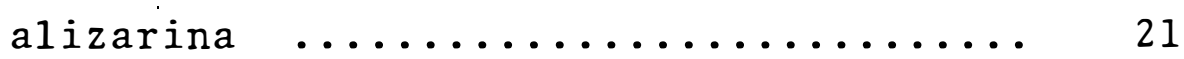

3.2.6. Fotografias das secçōes delgadas e frag mentos da rocha alterada $\ldots \ldots \ldots \ldots . . . .21$

3.2.7. Densidade da rocha fresca e das capas de

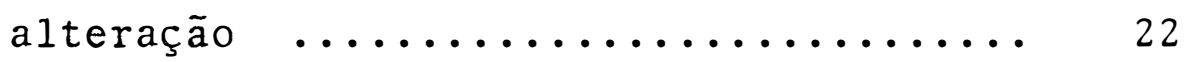

3.2.8. Determinação da umidade higroscópica e da higroscopicidade da fração argila .. 22

3.2.9. Expansão da vermiculita .......... 22

3.2.10. Determinação da capacidade de troca de cátions $\quad \ldots \ldots \ldots \ldots \ldots \ldots \ldots \ldots \ldots \ldots \ldots \ldots \ldots \ldots$ 


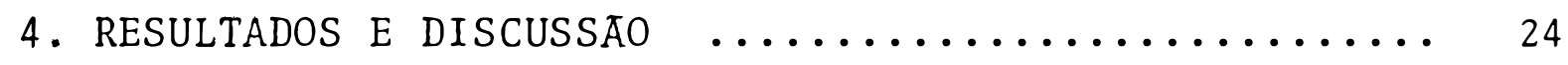

4.1. Anālise Granulométrica das Capas de Alteração .. 24

4.2. Densidade da Rocha Fresca e das Capas de altera

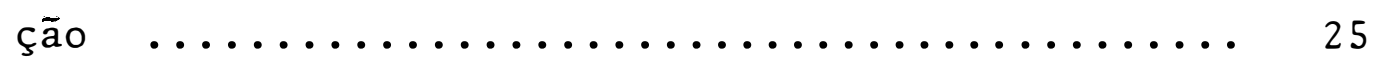

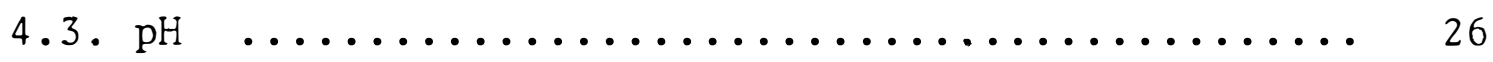

4.4. Anālise Química Total .................. 26

4.5. Característica da Fração Argila da Fase $F_{2} \ldots .28$

4.6. Anālises Química por Fluorescência de Raio-X .. 29

4.7. Exame de Secções Delgadas sob Microscópio de Po larização $\ldots \ldots \ldots \ldots \ldots \ldots . \ldots \ldots . . \ldots \ldots$

4.8. Anālise por Difração de Raio-X ........... 35

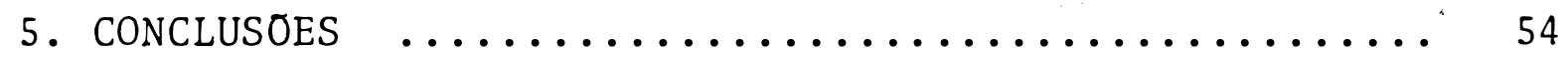

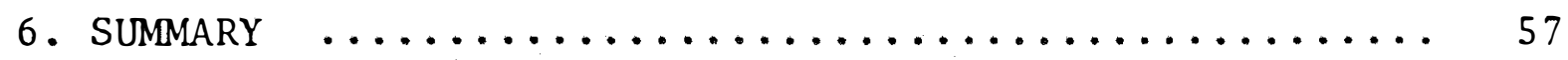

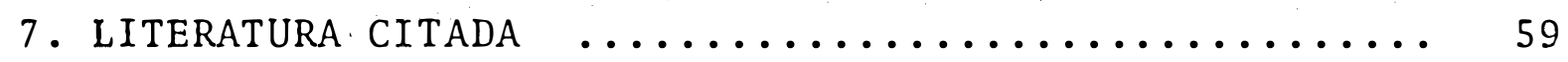


.vii.

LISTA DE QUADROS E FIGURAS

PAG.

QUADROS

I Resultados da Análise Granulométrica ...... 25

2 Resultados da Análise Química Total ....... 27

3 Resultados da Análise Química Total Corrigida para 100\%; Cálculos para Isoalumínio e Indices

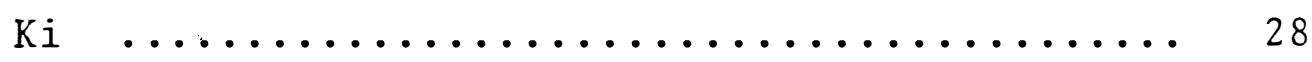

4 Indices Relativos "I" da Mobilidade dos Princi pais Elementos Químicos Durante a Intemperiza

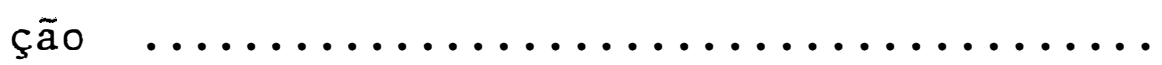

5 Resultados dos Difratogramas de Raios-X .... 36

FIGURAS

1 Gráfico da Anālise por Fluorescência de Raios$X$ da Rocha Fresca e da Argila da $2^{\text {a }}$. Fase de Al

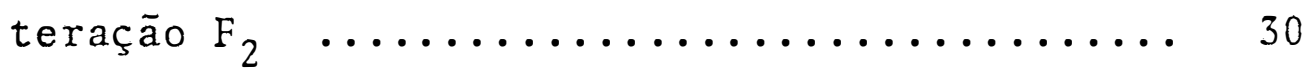

2 Gräfico da Anālise por Fluorescência de Raios$X$ da Rocha Fresca e das Fases de Alteração $F_{1}$

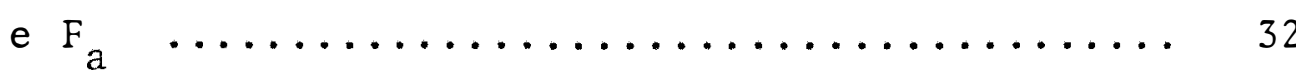

3 Digratogramas de Raios-X da Argila da 1. Fase de Alteração $\left(F_{1}\right) \quad \ldots \ldots \ldots \ldots \ldots \ldots \ldots \ldots \ldots \ldots$ 
4 Difratogramas de Raios-X da Fração $2 \mu-0,02 \mathrm{~mm}$ da 1 . Fase de Alteração $\left(F_{1}\right) \quad \ldots \ldots \ldots \ldots \ldots .6$

5 Difratogramas de Raios-X da Argila da 2a Fase de Alteração $\left(\mathrm{F}_{2}\right) \quad \ldots \ldots \ldots \ldots \ldots \ldots \ldots \ldots \ldots \ldots \ldots$

6 Difratogramas de Raios-X da Fração $2 \mu-0,02 \mathrm{~mm}$ da 2 . Fase de Alteração $\left(F_{2}\right) \quad \ldots \ldots \ldots \ldots \ldots, 41$

7 Difratogramas de Raios-X das Amostras: Argila$\mathrm{K}^{+}$, Argila Fina Natural, Argila Grossa Natural e Fração $>2 \mu$ Natural $\ldots . \ldots \ldots \ldots \ldots \ldots .42$

8 Difratogramas de Raios-X das Amostras: Mg-Satu radas (Argila e $>2 \mu$ ) das Fases $F_{1}$ e $F_{2} \ldots \ldots 43$ 
LISTA DE FOTOGRAFIAS

FOTOS

PAG .

1 Secção Delgada da Rocha Fresca $\ldots \ldots \ldots \ldots \ldots \ldots$

2 Secção Delgada da $1^{a}$. Fase de Alteração ....... 46

3 Secção Delgada da 2 . Fase de Alteração ....... 47

4;5;6 1. Fase de Alteração Natural e com os Reativos Ferrocianeto e Alizarina ................ 49

$7 ; 8 ; 9$ 2. Fase de Alteração Natural e com os Reativos Ferrocianeto e Alizarina $\ldots \ldots \ldots \ldots . \ldots . \ldots$

$10 \quad$ Vermiculita Expandida $\ldots \ldots \ldots \ldots \ldots \ldots \ldots$ 
RESUMO

O objetivo do presente trabalho é o estudo da altera ção de anfibolitos situados em condição de drenagem imperfe ta, mediante caracterizações analíticas da rocha fresca e das capas de alteração encontradas (fases de alteração).

A anālise granulométrica de duas distintas capas correntes revelou aumento nos teores de argila (fração infe rior a $0,002 \mathrm{~mm})$ e de silte $(0,053-0,002 \mathrm{~mm})$ na segunda fase de alteração, reflexo da demolição mais intensa das redes cris talinas dos minerais primários. As densidades da rocha fresca e das capas de alteração foram obtidas por pesagens de amos tras impermeabilizadas com saran dentro e fora da água, e os 
valores decrescem com o grau de alteração: 2,28; 2,09 e 1,14 $\mathrm{g} / \mathrm{cm}^{3}$, respectivamente. Também o pH decresce no mesmo sentido, passando de 8,3 a 7,4 e deste valor para 7,0 .

A análise química total da rocha fresca e da fração argila foi processada pela fusão com carbonato de sódio e os resultados mostram que as condições de incipiente drenagem $\underline{\text { a }}$ carretam pequena remoção de bases e sílica e tendência ao acú mulo de alumínio, com formação e permanência de minerais 2:1, como demonstram os resultados obtidos pela difração de raiosX. A fração argila da primeira fase de alteração apresenta pre dominantemente montmorilonita e caulinita, ao lado de mica, e na fração silte ocorrem vermiculita, mica, actinolita, caolin $\underline{i}$ ta e quartzo; na segunda fase de alteração a fração mais fina é constituída essencialmente por montmorilonita e ínfimas quan tidades de caulinita. Na outra fração aparecem montmorilonita, mica, caulinita e pequenas proporções de actinolita e quartzo.

As determinações por fluorescência de raios-X ev denciam uma tendência na concentração relativa dos elementos $\mathrm{Ti}, \mathrm{Cr}$ e Fe e uma perda de $\mathrm{Ca}$ e $\mathrm{Mn}$, enquanto o K e o $\mathrm{Si}$ mantêm-se mais ou menos constantes.

0 exame das secções delgadas sob microscópio de pola rização acusa, na rocha fresca, a presença de anfibolio verde (hornblenda), parcialmente transformado em actinolita, o pla gioclásio (andesina), parcialmente sericitizado e/ou saussuri tizado, com formação de apreciáveis quantidades de epidoto. Co mo accessórios aparecem a titanita, rara apatita e quartzo, e quase total ausência de opacos. Para a observação das fases de alteração ao microscópio, amostras indeformadas foram impregna 
das a vácuo com resina apropriada e confeccionadas as secções delgadas; na primeira fase de alteração ocorre intensa meteori zação dos plagioclásios e na outra capa os minerais alteram-se quase que totalmente em materiais argilosos e sericita, manten do-se ainda a estrutura original da rocha. Ao contrário da ro cha fresca, é notável nessa última fase concentrações localiza das de minerais opacos. As alterações referidas foram documen tadas em fotografias das secções delgadas.

Foram obtidas tambēm fotografias de fragmentos das fases de alteração tratados com alizarina e ferrocianeto de po tássio, possibilitanto asseverar que a nontronita provém do anfibólio, ao passo que a origem da caulinita é atribuída à alteração do plagioclásio.

Como dados complementares da fração argila foram de terminadas a umidade higroscópica - pesagens de amostras a $105-110^{\circ} \mathrm{C}$, a higroscopicidade - peso das amostras mantidas em câmara ümida com $\mathrm{H}_{2} \mathrm{SO}_{4} 1,49 \mathrm{~N}$ e ainda, a capacidade de troca catiônica pelos métodos do EDTA e do azul de metileno. A umida de higroscópica média foi de $17,09 \%$ e a média de higroscopicidade 31,0\%; a CTC pelo método do EDTA foi de 102 e.mg/100 g e pelo azul de metileno $98 \mathrm{e} . \mathrm{mg} / 100 \mathrm{~g}$.

A anālise dos resultados conduz às seguintes observa çōes :

- sob a condição de rochas encaixadas e consequente drenagem imperfeita os anfibólitos alteram-se produzindo mine rais de argila montmoriloníticos, mesmo sob condições de clima tropical úmido;

- na alteração estudada a hornblenda transforma-se 
transitoriamente em actinolita;

- sob condições de drenagem imperfeita o plagioclá sio (andesina) altera-se anteriormente ao anfibólio (hornblen da) ;

- a alteração do plagioclásio pode conduzir à formação direta de montmorilonita e caulinita ou à individualização de caulinita, seguindo-se uma ressilicatização para montmorilo nita;

- a montmorilonita proveniente do plagioclásio é de composição diferente da derivada do anfibólio, a primeira sen do mais aluminosa e a última ferrosa (nontronita);

- a formação de gibbsita a partir da alteração de plagioclásios em anfibölitos é inibida sob condições de drena gem deficitária;

- a vermiculita ocorre nas frações superiores a 2 mi cra e tem origem provável através de um processo de agradação; - para as condições de alteração do anfibolito estudado, a sílica sofre uma pequena perda por lixiviação, até as fases consideradas;

- o alumínio, ferro, titânio e cromo tendem a acumular-se, enquanto que o manganês é fortemente lixiviado;

- para as bases, observa-se uma lixiviação do cálcio, magnésio e potássio em ordem decrescente de intensidade, sendo que este último é bastante retido, provavelmente, nas mi cas e nas argilas da rede $2: 1$. 
Os processos de alteraçāo de minerais têm sido fre quentemente estudados, visando principalmente a ohtençāo de um melhor entendimento a respeito dos diferentes estágios de evo lução que levam à formação dos solos. Contudo, pouca atenção tem sido dada, em nosso meio, à intemperização sobre rochas frescas e seus produtos imediatos de alteraçāo.

Esses produtos, ou capas de alteração, mostram frequentemente as condições iniciais da climatização, e a sua ca racterização conduz a valiosas pistas para o entendimento de todo processo de alteracāo até as suas fases mais adiantadas.

Embora a maioria de nossos solos tenha sua gênese so bre um sedimento remanejado, muitas de suas características mi neralógicas, bem come as suas propriedades químicas e físicas 
.06 .

guardam estreita relaça com os processos iniciais do intempe rismo sobre as rochas de origem.

As rochas ferromagnesianas são de grande importância pela sua abundante contribuição como material de origem para os solos da região tropical brasileira. A alteração dessas ro chas merecem especial atenção devido a presença marcante do ferro como um dos fatores determinantes do intemperismo, prin cipalmente por sua alta sensibilidade aos mecanismos de oxiredução. Esses mecanismos são determinados principalmente pe las condições de drenagem e ação de compostos orgânicos provenientes da atividade biológica.

Paralelamente à importância dos estudos pedogenéti cos, as propriedades das argilas, muitas vezes formadas por condições específicas, são de especial interesse no uso industrial seja como elementos descorantes, como agentes tixiotrópi cos ou ainda para outras finalidades.

0 presente trabalho detém-se ao estudo da alteração de anfibolitos sob condições de drenagem imperfeita, localiza dos na região do Pré-Cambriano do Estado de São Paulo. 
A complexidade da composição química e estrutural dos minerais e suas associações, sofrendo a climatização, cau sam muitas dificuldades no estudo e interpretação dos produtos de alteração. E muito difícil definir com precisão o equilíbrio desse sistema, e a sua posição final não é de grande im portância, pois geralmente se lida com processos só parcialmen te completos. Por esta razão, os conhecimentos de climatização são, em sua maior parte, qualitativos e não quantitativos, não havendo meios de se prever com precisão o estado da rocha numa época futura (KRAUSKOFF, 1972).

Os solos de clima tropical comumente têm sido refer dos como provenientes de retrabalhamento de materiais pré-exis tentes, que na época de sua deposição jā se apresentavam com 
.08 .

certo grau de intemperismo (QUEIROZ NETO, 1969 ; RADWANSKI \& OLLIER, 1959 ; CARVALHO et alii, 1967 ; TEIXEIRA, 1962; GALHEGO, 1973; ESPINDOLA, 1973). A composição química e mineralógica desses sedimentos, na época de sua formação, dependia basica mente dos produtos de alteração das rochas circunvizinhas.

Os estudos detalhados de MOHR e VAN BAREN (1954) so bre a alteração de rochas básicas (diabásio) em clima tropical úmido e condições de boa drenagem mostraram que, mesmo nos primeiros estágios de alteração, formam-se apenas gibbsita, caulinita e óxido de ferro (goethita). Essa alteração é acom panhada de uma quase completa remoção de sílica e das basescálcio, magnésio, potássio e sódio, deixando um resíduo chama do laterita primária; em seguida ocorre um processo de ressili catização, resultando uma massa de laterita ou laterira argilą cea.

COLLIER (1961) ressalta que a literatura sobre alte ração de rochas em clima quente e ümido é extensa, porém a maior ênfase tem sido dada ao estudo dos estágios finais do processo de ferralitização, conduzindo à formação das lateri tas verdadeiras, constituídas quase que unicamente de hidróxi dos de ferro e alumínio, formadas sobretudo à expensas de ro chas básicas.

Uma medida das qualidades do meio, se mais ou menos lixiviado ou confinado, é o pH. As medidas do $\mathrm{pH}$ da solução de um nível de alteração, de um horizonte ou sedimento, qualifi cam, de um modo geral, a intensidade de renovação das äguas. Um meio ácido corresponde a uma lixiviação suficiente para eva cuação dos cátions básicos solúveis, e um meio alcalino é aque 
le mal drenado ou confinado, onde a perda de cátions básicos retarda-se ou estes acumulam-se (MILLOT, 1964).

As medidas de pH são de grande importância na interpretação do equilíbrio das reações químicas ocorridas durante o processo de alteração dos minerais (KRAUSKOFF, 1972).

As diversas fases de alteração de uma rocha são ca racterizadas por mudanças em cor, coerência, densidade, estado de oxidação e nas composições química e mineralógica. No entan to guardam relação, em diferentes graus, com a rocha de origem (MELFI \& LEVI, 1971).

$\mathrm{Na}$ primeira fase de alteração de granitos, correspon dente à formação de finas fissuras, principalmente nos plagioclásios, COLLIER (1961) observou o aparecimento de um produto caolinítico e um pouco de gibbsita. Refere-se também à concordância de todos autores em assinalar que as microclinas são mais resistentes que os plagioclásios, e que os minerais fer romagnesianos transformam-se em hidröxidos férricos. Em condi ções de má drenagem a montmorilonita pode formaæsse à partir de granitos mais básicos, restando, nas frações grosseiras, o quartzo e, dependendo da rocha, a muscovita e a hornblenda.

A relação existente entre a precipitação anual, quan tidade de lixiviação, remoção de sílica e bases e a natureza dos produtos de intemperismo, em rochas basálticas no Hawaii, foi mostrada por BATES (1962). A montmorilonita está sempre presente em áreas secas onde a lixiviação não removeu todas as bases; a haloisita e a alofana, em áreas com suficiente umida de para permitir lixiviação de bases, mas não de toda sílica; a alumina hidratada e géis de $\mathrm{Al}-\mathrm{Fe}$, em áreas permanentemente 
úmidas, ou com alternância de umidade e tempo suficiente para remover a sílica; ou ainda, laterita ou gibbsita, se ocorrem períodos secos.

SINGER (1966), estudando a fração argila da altera ção de basaltos sob condições de pequena precipitação pluviomé trica, verificou que a composição mineralógica é sobremaneira influenciada pela quantidade de precipitação pluviométrica, sendo o mineral dominante a montmorilonita, seguido pela caoli nita. Constatou ainda que com maiores precipitações o teor de montmorilonita decresce e o teor de caolinita e amorfos de $\mathrm{Fe}$ e Al aumentam.

ESPINDOLA (1973) verificou que a gibbsita não ocorre em solos lateríticos mal drenados, como também MAIGNIEN(1966), que, além da drenagem imperfeita, coloca a riqueza em sais co mo condição para a não ocorrência do referido mineral. Para LOSCHE (1970), o alto teor em sílica impede a formação de gibbsita.

Segundo NOVIKOFF (1974), a hornblenda transforma-se em montmorilonita quando a rocha se encontra em meio confina do; em anfibolitos, tanto os plagioclásios como a hornblenda participam da elaboração da smectita. A grande maioria dos minerais secundários são provenientes da alteração dos feldspa tos, que são ricos em alumínio, elemento pouco móvel, que ori enta a neogênese na direção dos minerais secundários ricos nes se elemento.

Para esse autor, ainda, a evolução dos produtos de alteração dos feldspatos são condicionados especialmente pela drenagem e pela natureza do mineral. Se a drenagem for rápida 
ocorre remoção de todos os elementos móveis, formando-se ape nas gibbsita; quando o contrário sobrevier, a condição de con finamento orienta a formação na direção da smectita, e, em sí tuações intermediārias de remoção, o tipo de minerais secundá rios individualizados é mais condicionado pela quantidade das soluçōes, em particular pelo teor de sílica e pela natureza do feldspato.

A alteração de anfibolitos tem sido correlacionada com a de rochas básicas. (basalto, diabase e gabro), sob condi ções de clima tropical (MELFI \& LEVI, 1971). Resultados da a teração dessas rochas básicas, em nossas condições, foram ob tidos por MONIZ et alii (1973), onde a grande variação encon trada na remoção de sílica e bases, sob mesmas condições climá ticas, sugere a investigação sobre outros fatores determinan tes dos processos de alteração.

Nos produtos do intemperismo de basaltos, SMITH(1957) encontrou a vermiculita como produto de alteração da olivina, enquanto que a caolinita era originária da labradorita, concor dando com FIELDS e SWINDLE (1954) e MITCHELL (1955), que afír mam que o tipo de mineral de argila presente nos solos depen de, em grande parte, dos minerais presentes na rocha de origem.

Para certos autores, a vermiculita tem uma origem hi drotermal, seja diretamente dos minerais primários (SHIMANE, 1969), seja a partir de um edifício cloritoso (CLABAUGH \& BAR NES, 1957), ou ainda a partir da biotita e da flogopita TEKHTINE, 1968). Para MONCHOUX (1961), a vermiculita forma-se diretamente no decurso da migmatização. Estudos realizados por 
MONCHOUX (1961) e CAILLERE \& FiENIN (1963) mostraram a presença de clorita alterada para vermiculita.

BASSET (1963) acredita que todas as vermiculitas de grande porte provém da alteração superficial de biotita e flo gopita.

A manutenção da vermiculita é favorecida pela alteração da hornblenda, que provoca um enriquecimento da solução em magnésio (NOVIKOFF, 1974). Na fração argila, JACKSON et alii (1952) admitem que a vermiculita possa provir da alteração da illita.

Dentre as argilas herdadas pela alteração direta das rochas, MILLOT (1964) assinala: biotitas alteradas em cloritas; cloritas em vermiculitas ou montmorillonita; muscovitas em ilita, vermiculita e montmorillonita. Como minerais neoformados são citados: sericita e, por vezes, montmorillonita, a partir de feldspatos e silicatos aluminosos e ainda a altera ção dos ferromagnesianos em clorita, eventualmente vermiculi ta, celladonita e montmorillonita. GRIM \& JOHNS (1954) constataram, no Golfo do México, um crescimento da illita e da clori ta a partir da montmorilonita.

Os processos de alteração química dos minerais desen volvem-se em presença de água e, em consequência, a mobilidade relativa dos íons em solução durante o intemperismo normalmen te orienta a gênese dos minerais a serem formados.

Para NOVIKOFF (1974), o comportamento do ferro é se melhante ao do alumínio, todavia com acúmulo mais moderado. A lixiviação do cálcio é intensa, porém incompleta, ao passo que o magnésio é fortemente evacuado, porém, com certo atraso em 
relação ao cálcio e sódio, em função do ataque mais tardio da biotita e da hornblenda, em comparação com os plagioclásios. A perda do potássio é gradual, e em estágios mais avançados da alteração subsiste em pequenas quantidades, tomando parte na composição das illitas e sericitas. O sódio é rápida e totalmente lixiviado.

Em rochas ígneas básicas, LEVI \& MELFI (1972) obsẹ varam uma perda gradativa de $\mathrm{Ca}-\mathrm{Na}-\mathrm{Mg}-\mathrm{K}-\mathrm{Si}$, em ordem decrescente, com uma tendência, no início, à retenção de cál cio e magnésio e perda de alumínio, seguindo-se uma retenção deste; este acúmulo é ainda mais evidente nos anfibolitos estu dados por aqueles autores. A perda de ferro estaria condiciona da a más condições de drenagem, propiciando provavelmente a sua remoção na forma bivalente. Nos anfibolitos a mobilidade do cálcio e do magnésio é semelhante, sendo retidos mais facil mente o titânio, o alumínio, o silício e o potássio.

KARPOFF (1973) (in NOVIKOFF, 1974) afirma que o titâa nio é fraca e regularmente lixiviado no processo de alteração; com a progressão da meteorização, a biotita e os anfibolios fornecem esse elemento.

Segundo observações de MONIZ et alii (1973) e NOVI KOFF (1974), o manganês é fortemente lixiviado no intemperismo de rochas ferromagnesianas.

Para KRAUSKOPF (1972) a separação do ferro do manga nês constitui-se em uma incógnita, pois seus comportamentos químicos reconstituídos a partir dos diagramas pH-EH são análo gos. E no entanto, localmente, compostos de manganês são encon trados com suficiente pureza, formando excelentes minérios. 
Afirma ainda que soluções obtidas diretamente pela climatização de rochas ígneas, ou pela ação de ácidos fortes sobre estas rochas, contém aproximadamente cinquenta vezes mais ferro do que manganês. A precipitação do manganês depois do ferro pode ser efetuada por uma das seguintes maneiras: sob a forma de óxidos se as condições são oxidantes e a solução se torna gradativamente mais alcalina; ou então sob a forma de carbonato ou silicato, se as condições são redutoras.

A relação $\mathrm{SiO}_{2} / \mathrm{Al}_{\mathrm{a}} \mathrm{O}_{3}$ (índice Ki) determina a orienta ção da gênese dos minerais de argila, e segundo MILLOT (1964), valores acima de 3,0 para essa relação fornecem condições para a formação dos minerais de argila do grupo $2: 1$, e para valores inferiores formam-se preferencialmente os minerais de argila do grupo $1: 1$.

GASTUCHE et alii (1962) em seus estudos sobre o as pecto coloidal da gênese dos minerais de argila salienta que - alumínio possui uma grande afinidade pela sílica para formar geis muito carregados, mas que a indução posterior é dependente do $\mathrm{pH}$ e do conteúdo de íons na solução. Um pH baixo e condi ções de dessaturação de eletrólitos favorecem a coordenação seis do aluminio e portanto argilas do tipo $1: 1$; à $\mathrm{pH}$ elevado e altos conteúdos de eletrólitos estabelecem a coordenação qua tro do alumínio aparecendo mais provavelmente minerais do gru po $2: 1$.

Vários mecanismos são susceptíveis para explicar a formação dos minerais argilosos:

a) evolução de uma massa amorfa que adquire espontâa nea e gradualmente um carăcter cristalino; tentativas de sínte 
se por esse mecanismo não conduziram a resultados satisfató rios;

b) evolução de uma massa amorfa à cristais graças a presença de cristais "germes";

c) fixação sobre uma fase jā cristalina ou pré-cris talina de material amorfo para a formação da nona fase cristalina;

d) evolução de uma fase cristalina à outra sem pas sar por uma fase de gel amorfo. 
.16 .

\section{MATERIAL E METODOS}

\subsection{Material}

Os anfibolitos foram coletados à margem esquerda da Ro dovia Castelo Branco-SP, à altura do quilômetro 38. As coordenadas da região situam-se entre $23^{\circ}-24^{\circ} \mathrm{S}$ e $46^{\circ} 47^{\circ} \mathrm{WG}$. As amos tras coletadas encontravam-se a aproximadamente $10 \mathrm{~m}$ de profun didade.

A região envolvida é caracterizada por uma precipita ção média anual de 1.100 a $1.500 \mathrm{~mm}$ e uma pequena variação sa zonal de umidade e temperatura.

Foi efetuada a coleta de duas distintas capas de alte 
ração e sua respectiva rocha viva. Aproximadamente $1 \mathrm{~kg}$ de ca da fase de alteração e fragmentos de rocha viva foram coleta dos, usando-se o critério baseado em diferenças de côr, coesão, densidade e estado de oxidação da rocha (MELFI \& LEVI, $1971)$

A primeira fase de alteração, denominada $F_{1}$, é caraç terizada por uma coloração cinza esbranquiçada com pontuações claras, decorrentes da alteração dos feldspatos, e apresenta ainda uma certa coeréncia e densidade elevada. A fase conside rada subsequente, denominada $F_{2}$, apresenta uma coloração verde claro, pequena densidade e uma incoerência entre os constituin tes. Nas regiões de maior facilidade de fendilhamento da rocha alterada aparece o mineral vermiculita, com dimensões que chegam a atingir vários milímetros de diâmetro.

Esses corpos anfiboliticos encontram-se estrutura mente concordantes com as rochas metamórficas regionais (micaxistos alterados). Esta situação dos anfibolitos provoca uma condição de drenagem interna imperfeita.

Segundo GOMES (1962), são resultantes de metamorfis mo dinamotermal sobre intrusivas básicas antigas. Anfibólios (hornblenda) e plagioclásios (andesina) constituem mais de 90\% da rocha; como accessórios ocorrem ainda a titanita, associada essencialmente ao anfibólio, rara apatita, além de quartzo se cundário.

O trabalho de SHAW (1954) mostra as relações existen tes entre a origem dos anfibolitos e a sua composição nos ele mentos menores e elementos traços.

No metamorfismo dinamotermal dos gabros não hā altẹ 
ração das concentrações iniciais de elementos tais como o cro mo, cobalto, níquel e o cobre; e inversamente, os anfibólitos de origens por substituição dos marmores tendem a ser deficien tes nestes elementos e a mostrar concentrações mais altas de bário e chumbo.

\subsection{Métodos de Análises}

3.2.1. Separação das frações granulométricas

A separação das frações granulométricas foi feita dispersando-se as amostras com água destilada em agitador rotati vo, e em seguida usando-se o método de sedimentação (lei de Stockes). As demais frações foram obtidas por peneiramento do material disperso, seco ao ar.

\subsubsection{Difração de raios-X}

Os difratogramas foram obtidos com um aparelho marca PHILIPS de raios-X operando com radiação $K-\alpha_{1}$ do cobre a $35 \mathrm{KV}$ e $20 \mathrm{~mA}$ com filtro de níquel. Para esta análise usou-se a fra ção silte $(0,002$ a $0,02 \mathrm{~mm})$ e a fração $\operatorname{argila~}(<0,002 \mathrm{~mm})$ de cada fase de alteração, tornando-se-as homoiônicas saturadas com potássio e magnésio e sob forma de amostras orientadas. Não houve necessidade de eliminação dos óxidos de ferro livres, pois estes encontram-se em infimas proporções no material estudado.

Para melhor identificação dos minerais, as amostras 
$\mathrm{Mg}^{++}$saturadas foram posteriormente glicoladas (com solução al coólica de glicol a $5 \%$ ) e as amostras $\mathrm{K}^{+}$saturadas aquecidas a $350^{\circ} \mathrm{C}$ e $550^{\circ} \mathrm{C}$. Os difratogramas foram obtidos entre os ângulos de 2 a 28 graus $\left(2{ }^{\circ}-2 \theta\right)$;em seguida os minerais foram identifica dos pelos seus espaçamentos basais característicos (MENDES, $1972)$.

3.2.3. Microscopia de polarização

As secções delgadas da rocha fresca, foram feitas, cor tando-se os fragmentos da rocha com serra de diamante na espessura de aproximadamente $4 \mathrm{~mm}$, polindo-se uma das faces com abrasivo e colando-se sobre lâmina de vidro para microscópio, com "Lakeside-70". Em seguida foram desgastadas com abrasivos de diferentes granas, até uma espessura aproximada de $30 \mathrm{mi}$ cra.

Para as fases de alteração subsequentes, em que a ro cha se encontra incoerente, fez-se impregnação à vácuo de tor rões indeformados com a resina Polylite T-213, usando-se a téc nica descrita em MENDES et alii (1973). Em seguida procedeu-se da mesma maneira que para a rocha fresca.

$\mathrm{Na}$ identificação dos minerais foram utilizados os méto dos ópticos usuais para microscopia de polarização.

\subsubsection{Anālises químicas quantitativas}

A rocha fresca e a fração argila da última fase de a teração foram analisadas pelo método de desintegração com 
$\mathrm{Na}_{2} \mathrm{CO}_{3}$ (KOLTHOFF \& SANDELL, 1952) com adaptações por informa ções verbais de PAIVA NETTO,J.E.de. Os silicatos são decompostos pela fusão com $\mathrm{Na}_{2} \mathrm{CO}_{3}$ (Anidro) em cápsula de platina a $900^{\circ} \mathrm{C}$, reagindo-se em seguida, com ácido clorídrico.

A sílica é desidratada em ácido clorídrico por seca gens sucessivas em banho-maria, sendo a seguir filtrada, lava da, queimada em forno mufla e pesada. No filtrado determinouse o ferro e o alumínio pelo método gravimétrico (KOLTHOFF ६ SANDELL, 1952), e as bases por espectrofotrometria de absorção atômica.

A avaliação da mobilidade dos constituintes, durante as alterações, foi processada com base nesses valores, pelo mé todo do isoalumínio que parte da suposição de que os teores de alumínio não mudam apreciavelmente durante 0 intemperismo (KRAUSKOFF, 1972 ) .

A āgua de constituição foi determinada em forno mu fla a $900^{\circ} \mathrm{C}$.

Foram realizadas, ainda, análises através de método semi-quantitativo por fluorescéncia de raios-X, de acordo com as recomendações contidas em SEIGNEMARTIN (1974), objetivandose o estudo da mobilidade relativa dos elementos químicos.

Os gráficos foram plotados de maneira a se obter uma informação visual rápida das tendências de concentração ou $1 \underline{i}$ xiviação. Estas análises foram complementadas pelo estabelecí mento de indices relativos (I); obtidos através da relação xistente entre as äreas dos picos característicos, dividindose os valores das fases de alteração pelos valores da rocha fresca. 
3.2.5. Reação com ferrocianeto de potássio e alizarina

A alizarina é um corante orgânico que apresenta a pro priedade de reagir com os octaédros de alumínio da estrutura cristalina dos minerais de argila, produzindo uma coloração vermelha, e também com os octaédros de ferro da rede cristali na dos minerais de argila 2:1, fornecendo uma coloração vinho. O ferrocianeto de potássio é outro reativo bastante sensível para os octaédros das estruturas cristalinas dos minerais de argila, e, neste caso, apenas os octaédros de ferro são reacio nados produzindo uma coloração azul ou verde (PAIVA NETO $\xi$ PACCOLA, 1973), enquanto que, os octaédros de alumínio permane cem inalterados.

Através da análise por reação de fragmentos de rocha alterada com os reativos ferrocianeto de potássio e alizarina pode-se constatar melhor a alteração dos minerais primários constituintes das rochas nos seus estágios evolutivos, pois que eles coram de maneira diversa os diferentes minerais de argila provenientes da alteração.

3.2.6. Fotografias das secções delgadas e fragmentos de rocha alterada

Esta técnica foi empregada para uma melhor ilustração da morfologia e dos graus de alteração dos diversos minerais nas diferentes fases de alteração da rocha. As fotos das sec çōes delgadas foram obtidas através de microscópio de polariza ção com polarizadores cruzados, com aumento de $116 \mathrm{X}$, enquanto 
que as fotos dos fragmentos de rocha alterada, tanto ao natu ral como com os reativos, foram obtidas através de lupa este reoscópica sob luz refletida, com aumento de 40 X.

3.2.7. Densidade da rocha fresca e das capas de altera ção

Para estas determinações usou-se o método da balança hidrostática, impermeabilizando-se as amostras das capas de al teração com resina Saran.

3.2.8. Determinação da umidade higroscópica e higroscô picidade da fração argila

A umidade higroscópica foi obtida tomando-se as amos tras secas ao ar e levando-se-as à estufa $\left(105-110^{\circ} \mathrm{C}\right)$ até peso constante.

A higroscopicidade foi obtida mantendo-se as amostras em câmara úmida $\left(\mathrm{H}_{2} \mathrm{SO}_{4} 1,49 \mathrm{~N}\right)$, até peso constante, e em segui da secas em estufa a $105-110^{\circ} \mathrm{C}$, também até peso constante.

3.2.9. Expansão da vermiculita

A vermiculita foi expandida por aquecimento rápido à $900^{\circ} \mathrm{C}$. Nessas condições a água contida entre as lâminas do mi neral vaporiza-se rapidamente, provocando a expansão do mine ral (PAIVA NETTO, J.E. de, informações verbais), sendo documen tado através de fotografia. 
3.2.10.Determinação da capacidade de troca de cátions da $\operatorname{argila}$

A capacidade de troca de cátions foi determinada pelo método do EDTA (GLORIA et alii, 1965) e pelo método do azul de metileno (PAIVA NETTO \& PACCOLA, 1974). 
.24 .

\section{RESULTADOS E DISCUSSAO}

4.1. Anālise granulométrica das capas de alteração

Os resultados apresentados no Quadro 1 possibilitam valiar a variação do grau de climatização apresentado pelas duas fases de alteração discriminadas.

Pelos aumentos dos teores na fração argila (menor que $0,002 \mathrm{~mm})$ e da fração silte $(0,053-0,002 \mathrm{~mm})$ na segunda fase de alteração $\left(F_{2}\right)$, infere-se que os minerais primärios tenham sofrido uma demolição de suas redes cristalinas mais intensa mente nessa fase, tornando a rocha progressivamente mais inco erente. 
Quadro 1. Resultados da análise granulométrica.

\begin{tabular}{|c|c|c|}
\hline Fração (mm) & $\begin{array}{c}1 \stackrel{\text { a fase de al }}{ } \\
\text { teração }\left(\begin{array}{l}o \\
0\end{array}\right)\end{array}$ & $\begin{array}{l}2^{\mathrm{a}} \text { fase de a1 } \\
\text { teração }\left(\begin{array}{l}0 \\
0\end{array}\right)\end{array}$ \\
\hline maior que 2,0 & 5,89 & 2,68 \\
\hline $2,0-1,0$ & 7,88 & 6,47 \\
\hline $1,0-0,5$ & 12,96 & 9,43 \\
\hline $0,5-0,250$ & 13,20 & 9,46 \\
\hline $0,250-0,125$ & 12,50 & 10,22 \\
\hline $0,125-0,053$ & 16,71 & 12,83 \\
\hline $0,053-0,002$ & 27,07 & 30,48 \\
\hline menor que 0,002 & 3,79 & 18,43 \\
\hline Total & 100,00 & 100,00 \\
\hline
\end{tabular}

Um fato que deve ser salientado é a pequena mudança de coloração a partir da rocha fresca atē a ültima fase de al teração estudada, passando de verde escuro a verde claro, evi denciando à pequena formação de óxidos de ferro livres.

4.2. Densidade da Rocha Fresca e das Capas de Alteração

Os valores de densidade variaram de $2,98 \mathrm{~g} / \mathrm{cm}^{3}$ na ro cha fresca para $2,09 \mathrm{~g} / \mathrm{cm}^{3}$ e $1,14 \mathrm{~g} / \mathrm{cm}^{3}$ para a primeira e se gunda fases de alteração respectivamente. Estes dados eviden ciam os diferentes graus de alteração das duas fases, mostran do a grande intensidade de alteração ocorrida pelos processos 
de climatização dos minerais primários.

4.3. $\mathrm{pH}$

As anālises de pH efetuadas revelam uma variação de um valor de 8,3 para a rocha viva ( $\mathrm{pH}$ de abrasão) à 7,4 para a primeira fase de alteração e 7,0 para a segunda fase.

De acordo com MILLOT (1964) esses dados indicam que as condições de drenagem são imperfeitas ou de confinamento, o que é compatível com a posição encaixada em que se encontra o anfibólito estudado, revelando ainda que as bases e a sílica foram relativamente pouco lixiviadas, propiciando condições ideais para formação de minerais $2: 1$.

4.4. Anālise Química Total

Os resultados da análise química total da rocha fres ca e da fração argila da segunda fase de alteração são apresen tados no Quadro 2, e referem-se à médias de 3 repetições e com base no peso seco a $105-110^{\circ} \mathrm{C}$.

No Quadro 3 as colunas I e II mostram os resultados da análise química corrigidos para $100 \%$ para a rocha fresca e a fração argila da segunda fase de alteração, respectivamente. A coluna A representa as quantidades remanescentes para cada $100 \mathrm{~g}$ de rocha fresca e a coluna B as quantidades lixiviadas para a mesma quantidade de rocha. A coluna $C$ indica o aumento em porcentagem ou diminuição de cada constituinte. 
Quadro 2. Resultados da análise química total.

\begin{tabular}{ccc} 
Constituinte & Rocha Fresca & Fração \\
\hline $\mathrm{SiO}_{2}$ & $\operatorname{Argila}_{\substack{0 \\
0}}\left(\mathrm{~F}_{2}\right)$ \\
$\mathrm{Fe}_{2} \mathrm{O}_{3}$ & 48,70 & 51,47 \\
$\mathrm{Al}_{2} \mathrm{O}_{3}$ & 24,30 & 23,52 \\
$\mathrm{CaO}$ & 7,39 & 10,55 \\
$\mathrm{MgO}$ & 14,17 & 4,36 \\
$\mathrm{~K}_{2} \mathrm{O}$ & 5,91 & 2,20 \\
$\mathrm{H}_{2} \mathrm{O}^{+}$ & 0,42 & 0,12 \\
\hline Total & 0,58 & 8,51 \\
\hline
\end{tabular}

A análise dos resultados permite afirmar que, apesar da concentração relativa da sílica, ocorre uma perda por lixi viação da ordem de $25,94 \%$ do seu total original.

Em relação ao ferro, constata-se uma perda deste ele mento, resultado concordante com o obtido por LEVI \& MELFI (1972), que afirmam ocorrer uma perda desse elemento na forma de $\mathrm{Fe}^{2+}$, como decorrência do ambiente redutor resultante das condições de má drenagem.

As bases cálcio, magnésio e potássio sofreram uma lixiviação da ordem de $78,90 \%, 73,89 \%$ e $78,05 \%$, respectivamente, indicando que a alteração dos feldspatos precedem aos anfí bólios permitindo a maior saída do Ca do sistema k acumulando se na fração $>2 \mu$. 
Quadro 3. Resultados da análise química total corrigidos para $100 \%$, cálculos para isoalumínio e índices Ki.

\begin{tabular}{|c|c|c|c|c|c|}
\hline $\begin{array}{l}\text { Consti } \\
\text { tuinte }\end{array}$ & $\begin{array}{c}\text { I } \\
\text { Rocha } \\
\text { Fresca } \\
\frac{0}{\sigma} \\
\end{array}$ & $\begin{array}{c}\text { II } \\
\text { Argila } \\
\mathrm{F}_{2} \\
\frac{0}{0}\end{array}$ & $A$ & $B$ & $\begin{array}{l}C \\
\because\end{array}$ \\
\hline $\mathrm{SiO}_{2}$ & 48,00 & 51,47 & 35,55 & $-12,45$ & $-\quad 25,94$ \\
\hline $\mathrm{Fe}_{2} \mathrm{O}_{3}$ & 23,90 & 22,79 & 15,73 & $-8,23$ & $-34,35$ \\
\hline $\mathrm{Al}_{2} \mathrm{O}_{3}$ & 7,28 & 10,55 & 7,28 & 0 & 0 \\
\hline $\mathrm{CaO}$ & 14,02 & 4,36 & 3,01 & $-11,25$ & $-78,90$ \\
\hline $\mathrm{MgO}$ & 5,82 & 2,20 & 1,52 & $-4,30$ & $-\quad 73,89$ \\
\hline $\mathrm{K}_{2} \mathrm{O}$ & 0,41 & 0,12 & 0,09 & $-0,32$ & $-78,05$ \\
\hline $\mathrm{H}_{2} \mathrm{O}^{+}$ & 0,57 & 8,51 & 5,88 & $+5,31$ & $+931,58$ \\
\hline Total & 100,00 & 100,00 & 68,89 & 31,24 & - \\
\hline $\mathrm{Ki}$ & 6,78 & 4,77 & - & - & - \\
\hline
\end{tabular}

Os Indices $\mathrm{Ki}$ acima de 3,0 indicam condições ideais para formação de minerais de argila do grupo $2: 1$, como afirma MILLOT (1964).

4.5. Características da Fração Argila da Fase $F_{2}$

As determinações efetuadas forneceram uma média de $17,09 \%$ para a umidade higroscópica, 31,0\% para a higroscopicí dade, 102 e.mg/100 g para a CTC pelo método do E.D.T.A. e 
98 e.mg/100 g para a CTC pelo método do azul de metileno. Os altos valores, aqui obtidos para esses parâmetros, também indi cam a ocorrência de minerais do grupo $2: 1$.

4.6. Anālises Químicas por Fluorescência de Raio-X

As Figuras 1 e 2 fornecem uma rāpida informação vi sual sobre as tendências de movimentação dos diversos elemen tos químicos durante o processo de alteração, que são comple mentadas pelo estabelecimento de índices relativos (I)*, cons tantes do Quadro 4. Os dados mostram uma concentração do alumí nio na fração argila $\left(I_{A 1}=1,34\right)$.

O silício tende a permanecer constante da rocha para a primeira fase de alteração $\left(I_{S i}=1,00\right)$, ocorrendo uma perda para a segunda fase $\left(I_{S i}=0,73\right)$, concentrando-se, porém, na fração argila $\left(I_{S i}=1,26\right)$. O potássio mantém-se mais ou menos constante durante o processo de alteração $\left(I_{K}=1,00\right.$ e 0,98), diminuindo, contudo, na fração argila $\left(I_{K}=0,09\right)$. Este resul tado conduz à suposição de que a mica e vermiculita existem em maior proporção nas frações acima de 2 micra, admitindo-se que aquele elemento encontra-se, em sua maior parte, nesses minerais.

O cálcio é o elemento mais móvel, sofrendo uma perda porcentualmente grande durante a intemperização $\left(_{C a}=0,62\right.$; $0,27 ; 0,10)$.

* A letra I quando seguida do símbolo dos elementos químicos, refere-se ao índice do elemento correspondente. 
.30 .

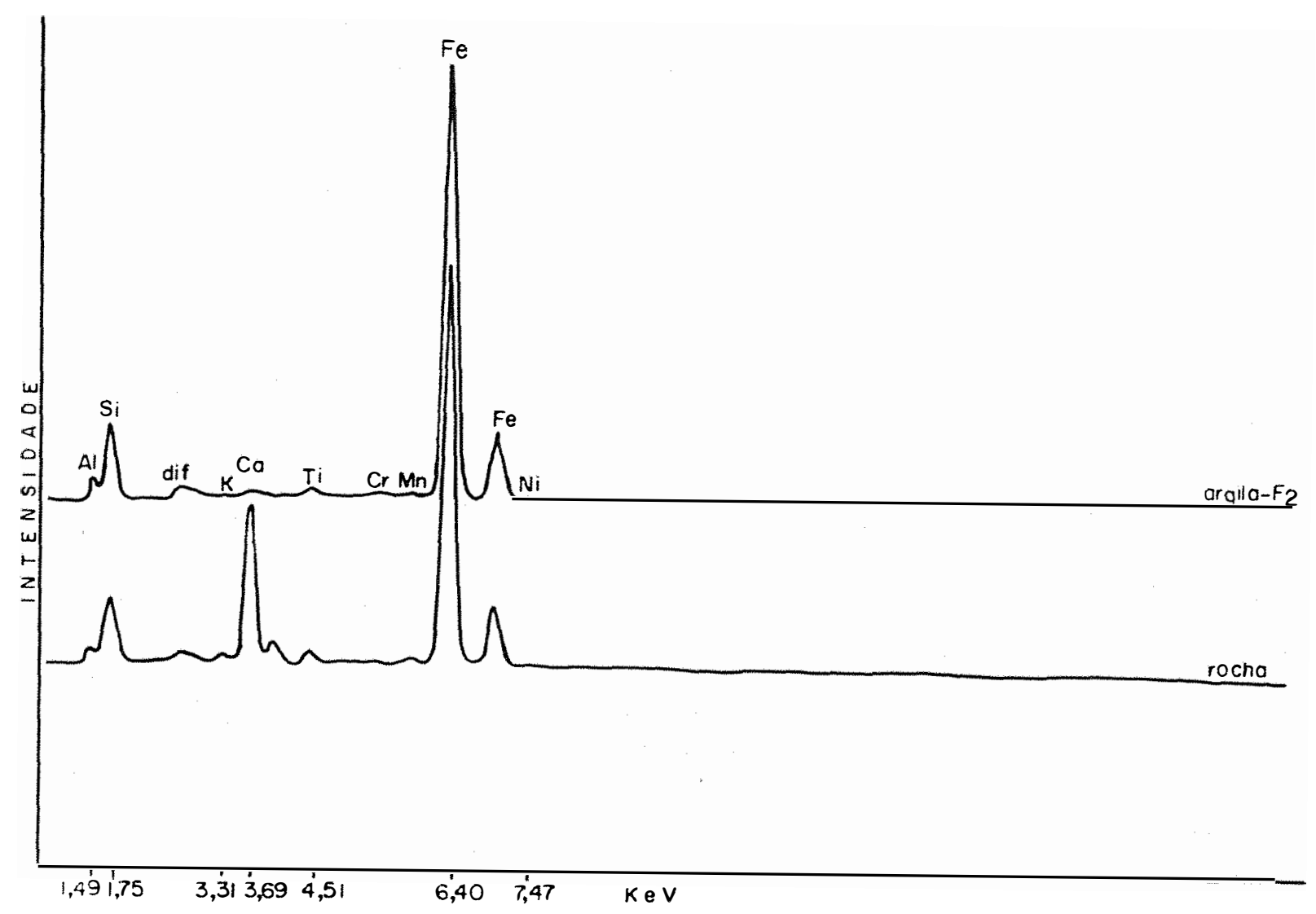

Figura 1: Curvas analíticas obtidas com equipamento de fluores cência de raios-X marca FINNIGAN, operando a $15 \mathrm{KV} /$ $2,3 \mu \mathrm{A} / \mathrm{vācuo} / 100 \mathrm{seg}$. 
Tanto o titânio, como o cromo são elementos muito pouco móveis, tendendo a uma concentração na sequência de alte ração, existindo, contudo em teores baixos na fração argila $\left(\mathrm{I}_{\mathrm{Ti}}=2,12 ; 2,62 ; 0,46 \mathrm{e} \mathrm{I}_{\mathrm{Cr}}=1,25 ; 2,25 ; 0,14\right)$. A pequena mobilidade do titânio é também relatada por KARKOFF (1973).

A mobilidade do manganês é bastante acentuada, com cordando com as observações realizadas por MONIZ et alii (1973) e NOVIKOFF (1973) para rochas ferromagnesianas, e compatível com o ambiente redutor.

Estes dados sobre a mobilidade do manganês neste ti po de alteração onde ocorre também uma concentração do ferro faz-nos volver às observações de KRAUSKOPF (1972) com relação as possíveis hipóteses da geoquímica de separação dos dois ele mentos. Podemos afirmar então, baseados em nossos dados e dos demais autores acima, que existem certas condições de altera ção de rochas na natureza, onde as mobilidades do ferro e do manganês são diferentes daquelas citadas por KRAUSKOPF para alteração natural ou artificial das rochas ígneas básicas.

Nas condições estudadas, o manganês é evacuado do sistema na forma de carbonatos ou silicatos, enquanto o ferro sofre um acúmulo na forma de silicatos (minerais de argila-non tronita), conforme indicam os indices $\mathrm{I}_{\mathrm{Mn}} \mathrm{e} \mathrm{I}_{\mathrm{Fe}}$.

Este mecanismo presente na maioria das alterações de rochas básicas em ambiente confinado, constitui-se provavel mente, num dos meios pelos quais, na natureza, ocorre a separa ção do ferro do manganês.

As considerações aqui efetuadas para o alumínio, si lício, titânio e potássio são semelhantes àquelas obtidas por 


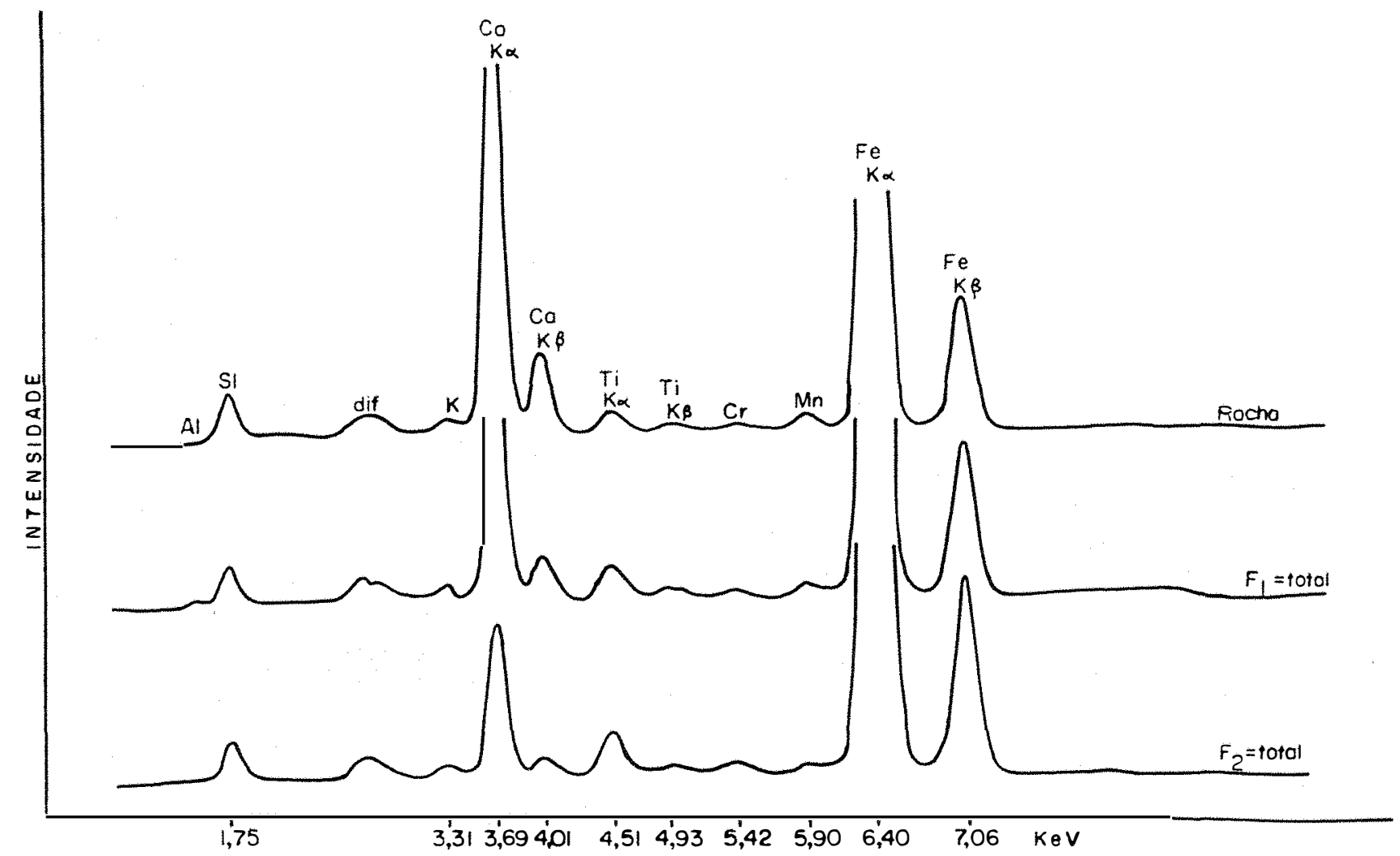

Figura 2: Curvas analiticas obtidas com equipamento de fluorescen cia de raios-X marca FINNIGAN, operando a $15 \mathrm{KV} / 0,2 \mathrm{~mA} /$ $8 \mathrm{gain} /$ U.F.S. 16K/200 seg. 
LEVI \& MELFI (1972) para anfibolitos.

Quadro 4. Indices relativos da mobilidade dos principais ele mentos químicos durante a intemperização.

\begin{tabular}{cccc}
\hline Elemento & \multicolumn{3}{c}{ INDICES RELATIVOS (I) } \\
\cline { 2 - 4 } & $\mathrm{R} / \mathrm{F}_{1}$ & $\mathrm{R} / \mathrm{F}_{2}$ & $\mathrm{R} / \mathrm{ARG} . \mathrm{F}_{2}$ \\
\hline $\mathrm{Al}$ & $(-)$ & $(-)$ & 1,34 \\
$\mathrm{Si}$ & 1,00 & 0,73 & 1,26 \\
$\mathrm{~K}$ & 1,00 & 0,98 & 0,29 \\
$\mathrm{Ca}$ & 0,62 & 0,27 & 0,05 \\
$\mathrm{Ti}$ & 2,12 & 2,62 & 0,46 \\
$\mathrm{Cr}$ & 1,25 & 2,25 & 0,14 \\
$\mathrm{Mn}$ & 0,80 & 0,30 & 0,50 \\
$\mathrm{Fe}$ & 1,48 & 1,55 & 1,12 \\
\hline
\end{tabular}

O Quadro 4 mostra ainda, em valores absolutos, uma concentração do ferro com a evolução da alteração $\quad\left(I_{F e}=\right.$ $1,48 ; 1,55 ; 1,2)$ a despeito da ausência de coloração avermelha da característica dos óxidos desse elemento, revelando que dü rante o processo de alteração há ocorrência de intensa substituição isomorfa do Al pelo Fe na rede cristalina do mineral de argila neogênico, o que leva à formação da nontronita. 
4.7. Exame de Seç̧ōes Delgadas sob Microscōpio de Polariza ção

O exame das lâminas da rocha fresca indica tratar-se de um anfibolito com ligeira alteração. A rocha é formada es sencialmente por cristais anedrais a sub-edrais de anfibólio verde (hornblenda), de disposição isotrópica e parcialmente transformada em actinolita. Localmente observa-se o desenvol vimento de estrutura poiquilítica entre hornblenda e plagioclā sio.

0 plagioclásio (andesina) ocupa posição predominan temente intersticial em relação à hornblenda, e mostra-se par cialmente sericitizado e/ou saussuritizado, com a formação de apreciáveis quantidades de epidoto. Esses minerais ostentam também, formas predominantemente sub-edrais e anedrais.

Ocorrem ainda, como acessórios, a titanita associada essencialmente ao anfibólio, rara apatita além de quartzo in tersticial secundārio.

E notável a ausência quase total de minerais opacos.

$\mathrm{Na}$ primeira fase de alteração acentua-se extraordina riamente a deterioração do plagioclásio, permanecendo intacta apenas parte do anfibólio e epidoto.

$E$, entretanto, mantida ainda plenamente a estrutura da rocha original.

Em sequência, com a deterioração progressiva, ocorre a destruição praticamente total dos minerais pré-existentes, com a sua transformação em minerais argilosos e sericita, acom 
panhada da liberação de pequena quantidade de quartzo secundá rio.

Mesmo nesta fase é ainda mantida a estrutura orig nal da rocha, com o ressalto dos antigos cristais de anfibólio, por concentraçōes locais de minerais opacos, sob a forma de pseudomorfose.

0 aspecto da lâmina sugere a ausência de movimenta ção da capa de alteração após sua formação.

4.8. Análise por Difração de Raios-X

Os resultados obtidos encontram-se nas Figuras 3 a 8 e o Quadro 5 apresenta um resumo dos espaçamentos basais refe rentes à difração de 1 a ordem.

Para a primeira fase de alteração são encontradas na fração argila, predominantemente a montmorilonita e a caolini ta e em pequenas proporçōes mica e actinolita, (Figura 3), en quanto que na fração maior que 2 micra aparecem intensamente os minerais vermiculita, mica, actinolita, caolinita e pouco quartzo (Figura 4). A presença de actinolita e ausência de pla gioclásios confirmam as verificaçōes obtidas nas secçōes delga das, de que o feldspato já se encontra totalmente alterado e, a hornblenda transformada transitoriamente em actinolita, apa recendo também o quartzo secundário.

Na fase 2 de alteração (Figura 5) a fração argila é constituída essencialmente de montmorilonita, com infimas quan tidades de caolinita. A fração maior que 2 micra desta fase de alteração é representada pelos minerais: montmorilonita, mi 
Quadro 5. Resultados dos difratogramas de raios-X; espaçamento basal dos principais minerais presentes, referentes a difração de 1 . ordem.

\begin{tabular}{|c|c|c|c|c|c|c|c|}
\hline \multirow{2}{*}{ Frações } & \multirow{2}{*}{$\begin{array}{l}\text { Fases de } \\
\text { alteração }\end{array}$} & \multicolumn{6}{|c|}{ ESPAÇAMENTO BASAL (Angstrons) } \\
\hline & & N & $M g-G$ & $\mathrm{Mg}$ & K & $\mathrm{K}-350^{\circ} \mathrm{C}$ & $\mathrm{K}-550^{\circ} \mathrm{C}$ \\
\hline \multirow{4}{*}{0,053} & \multirow{5}{*}{$\mathrm{F}_{1}$} & 14,2 & 14,2 & 14,2 & 12,4 & - & - \\
\hline & & 10,0 & 10,0 & 10,0 & 10,0 & 10,0 & 10,0 \\
\hline & & 8,4 & 8,4 & 8,4 & 8,4 & 8,4 & 8,4 \\
\hline & & 7,2 & 7,2 & 7,2 & 7,2 & 7,2 & 7,2 \\
\hline \multirow[t]{2}{*}{ a } & & 3,3 & 3,3 & 3,3 & 3,3 & 3,3 & 3,3 \\
\hline & \multirow{5}{*}{$\mathrm{F}_{2}$} & 16,0 & 16,0 & 16,0 & 12,4 & 12,4 & - \\
\hline \multirow[t]{4}{*}{$0,002 \mathrm{~mm}$} & & 10,0 & 10,0 & 10,0 & 10,0 & 10,0 & 9,9 \\
\hline & & 8,4 & 8,4 & 8,4 & 8,4 & 8,4 & 8,4 \\
\hline & & 7,2 & 7,2 & 7,2 & 7,2 & 7,2 & 7,2 \\
\hline & & 3,3 & 3,3 & 3,3 & 3,3 & 3,3 & 3,3 \\
\hline \multirow{3}{*}{ Menor } & \multirow{4}{*}{$\mathrm{F}_{1}$} & 12,4 & 18,0 & 16,0 & 12,4 & - & - \\
\hline & & 10,0 & 10,0 & 10,0 & 10,0 & 10,0 & 9,8 \\
\hline & & 8,4 & 8,4 & 8,4 & 8,4 & 8,4 & - \\
\hline \multirow[t]{2}{*}{ que } & & 7,2 & 7,2 & 7,2 & 7,2 & 7,2 & - \\
\hline & & 16,0 & 16,0 & 16,0 & 12,4 & - & - \\
\hline \multirow[t]{4}{*}{$0,002 \mathrm{~mm}$} & $\mathrm{~F}_{2}$ & 10,0 & 10,0 & 10,0 & 10,0 & 10,0 & 9,0 \\
\hline & & 7,2 & 7,2 & 7,2 & 7,2 & 7,2 & - \\
\hline & $\mathrm{F}_{2}-\frac{\operatorname{argila}}{\operatorname{grossa}}$ & 16,0 & - & - & - & - & - \\
\hline & $\mathrm{F}_{2^{-}} \underset{\text { fina }}{\operatorname{argila}}$ & 12,4 & - & - & - & - & - \\
\hline
\end{tabular}

$\mathrm{N}=$ natural; $\mathrm{Mg}-\mathrm{G}=$ magnésio saturada glicolado; $\mathrm{Mg}=$ magnésio saturada; $\mathrm{K}=$ potássio saturada; $\mathrm{K}-350^{\circ} \mathrm{C}=$ potássio saturada, aquecida a $350^{\circ} \mathrm{C} ; \mathrm{K}-550^{\circ} \mathrm{C}=$ potássio saturada, aquecida a $550^{\circ} \mathrm{C}$. 
ca, caolinita e ainda pequenas proporções de actinolita quartzo (Figura 6). Pela análise química total pode-se dizer que a montmorilonita formada apresenta uma intensa substitui ção do alumínio por ferro, dando origem à nontronita, fato es te, que permite explicar a concentração de ferro, referida an teriormente, e consequentes valores superiores a 1,00 para os indices relativos $\left(I_{F e}\right)$. Assim podemos inferir que o ferro $1 \underline{i}$ berado no processo de alteração estaria sendo utilizado na sín tese da nontronita, não se formando os óxidos de ferro livres, que produziriam coloraçōes avermelhadas ao material intemperi$z$ ado.

Por intermédio da difração de raios-X verifica - se que os minerais de argila.do grupo da montmorilonita compor tam-se de maneira diversa, quando se comparam as duas fases de alteração. Na primeira fase, tanto a amostra natural como a $\mathrm{K}^{+}$saturada revelam o espaçamento basal de $12,4 \AA$; na $\mathrm{Mg}^{2+} \mathrm{sa}$ turada o valor é de $16 \AA$, que se expande a 18 Angstrons, quan do essa amostra é solvatada com etileno-glicol, como pode ser observado na Figura 3. Entretanto, na segunda fase, tanto na amostra natural como na $\mathrm{Mg}^{2+}$ saturada ou na glicolada o espaça mento basal dos minerais daquele grupo é de 16 que reduz-se a 12,4 \& quando a argila é saturada com $K^{+}$(Figura 5).

Esses resultados levam-nos a deduzir que a maior par te da montmorilonita formada durante a primeira fase de alteração é origināria do feldspato e portanto encontrando-se natu ralmente saturada com potássio.

Como, na primeira fase de alteração o anfibólio está pouco alterado, a maior parte do $\mathrm{Mg}^{2+}$ encontra-se na rede cris 


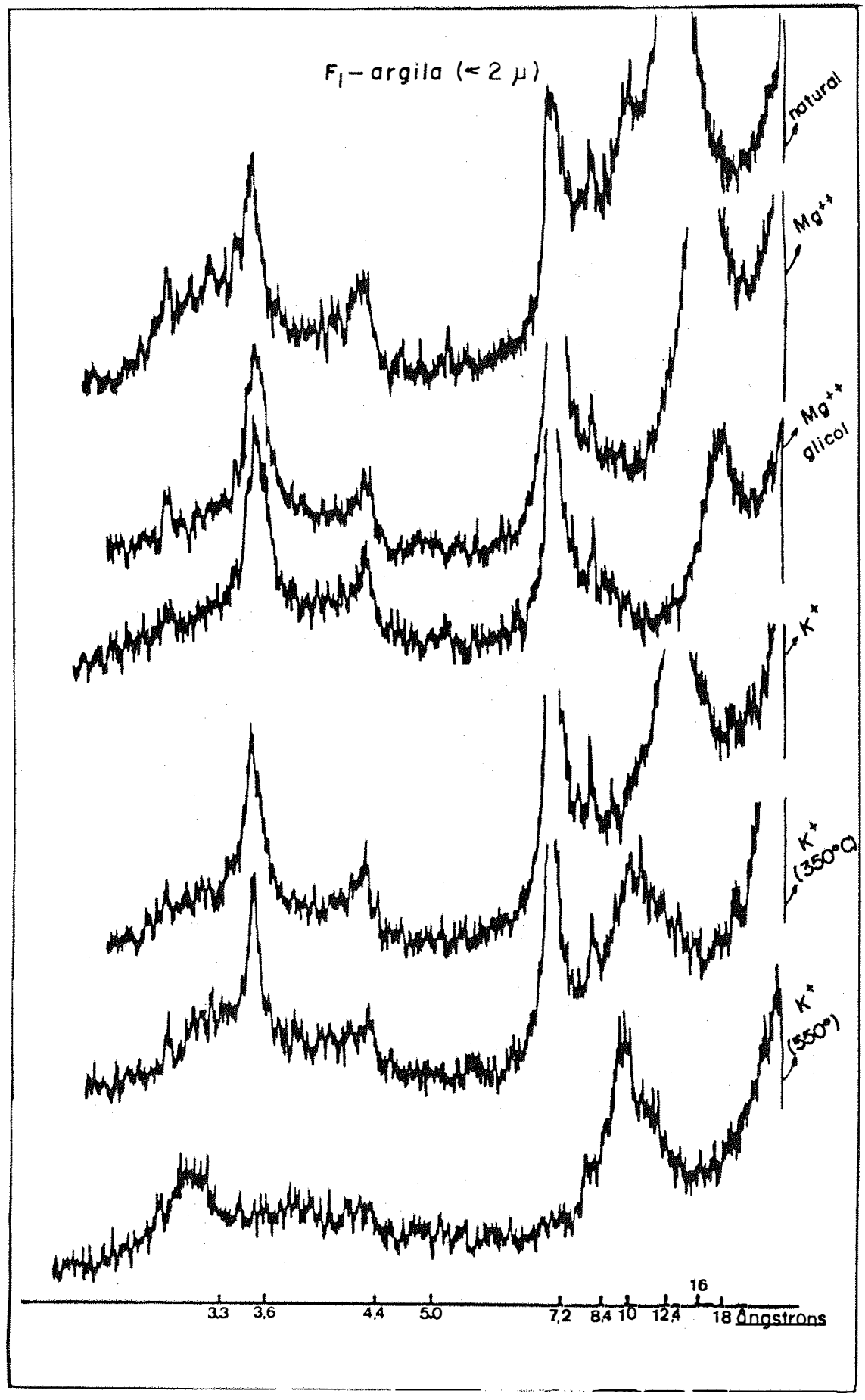

Figura 3. Difratogramas de raios-X da fração argila $(<2 \mu)$ da primeira fase de alteração $\left(F_{1}\right)$, obtidas em equipamento Phillips, operando a $35 \mathrm{KV}$ e 20mA, com radiação $\mathrm{Kal}$ do $\mathrm{G}$ e filtro de níquel. Naturalsaturação natural; $\mathrm{Mg}^{++}$-glicol-saturada com magnésio e glicolada; $\mathrm{Mg}^{++}$-saturada com magnésio; $\mathrm{K}^{+}$-saturada com potássio; $\mathrm{K}^{+}-350^{\circ} \mathrm{C}$-sa turada com potássio e aquecida a $350^{\circ} \mathrm{C} ; \mathrm{K}^{+} 550^{\circ} \mathrm{C}$-saturada com po tássio e aquecida a $550^{\circ} \mathrm{C}$. 


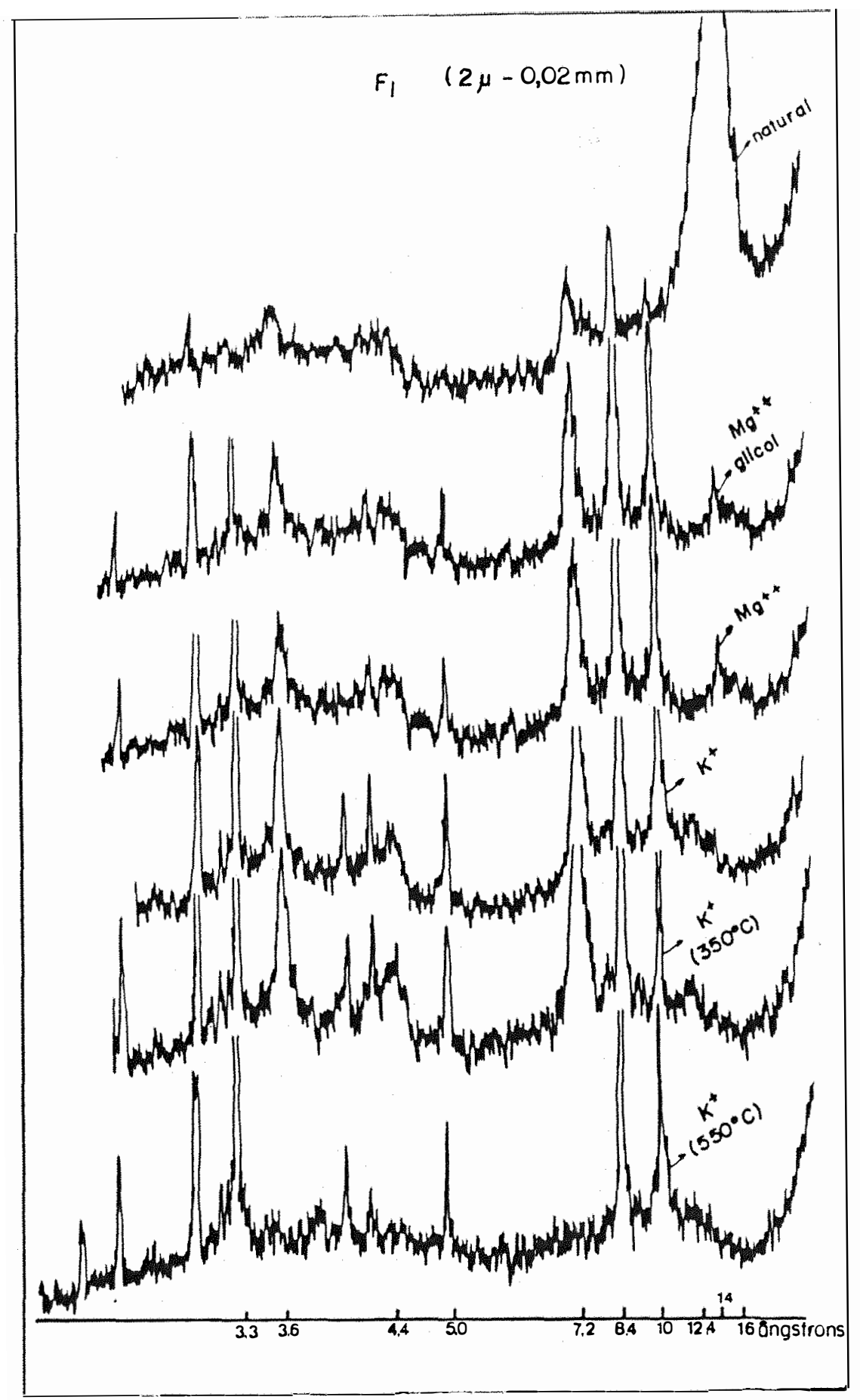

Figura 4. Difratogramas de raios-X da fração $2 \mu-0,02 \pi m$ da primeira fase de alteração $\left(F_{1}\right)$, obtidos em equipamento Phillips, operando a $35 \mathrm{KV}$ e $20 \mathrm{~mA}$, com radiação $K \alpha 1$ do $\mathrm{Cu}$ e filtro de níquel.Natural-satura ção natural; $\mathrm{Mg}^{++}$-glicol-saturada com magnésio e glicolada; $\mathrm{Mg}^{++}$ saturada com magnésio; $\mathrm{K}^{+}$-saturada com potássio; $\mathrm{K}^{+}-350^{\circ} \mathrm{C}$-satura rada com potássio e aquecida a $350^{\circ} \mathrm{C} ; \mathrm{K}^{+}-550^{\circ} \mathrm{C}$-saturada com po tássio e aquecida a $550^{\circ} \mathrm{C}$. 
.40 .

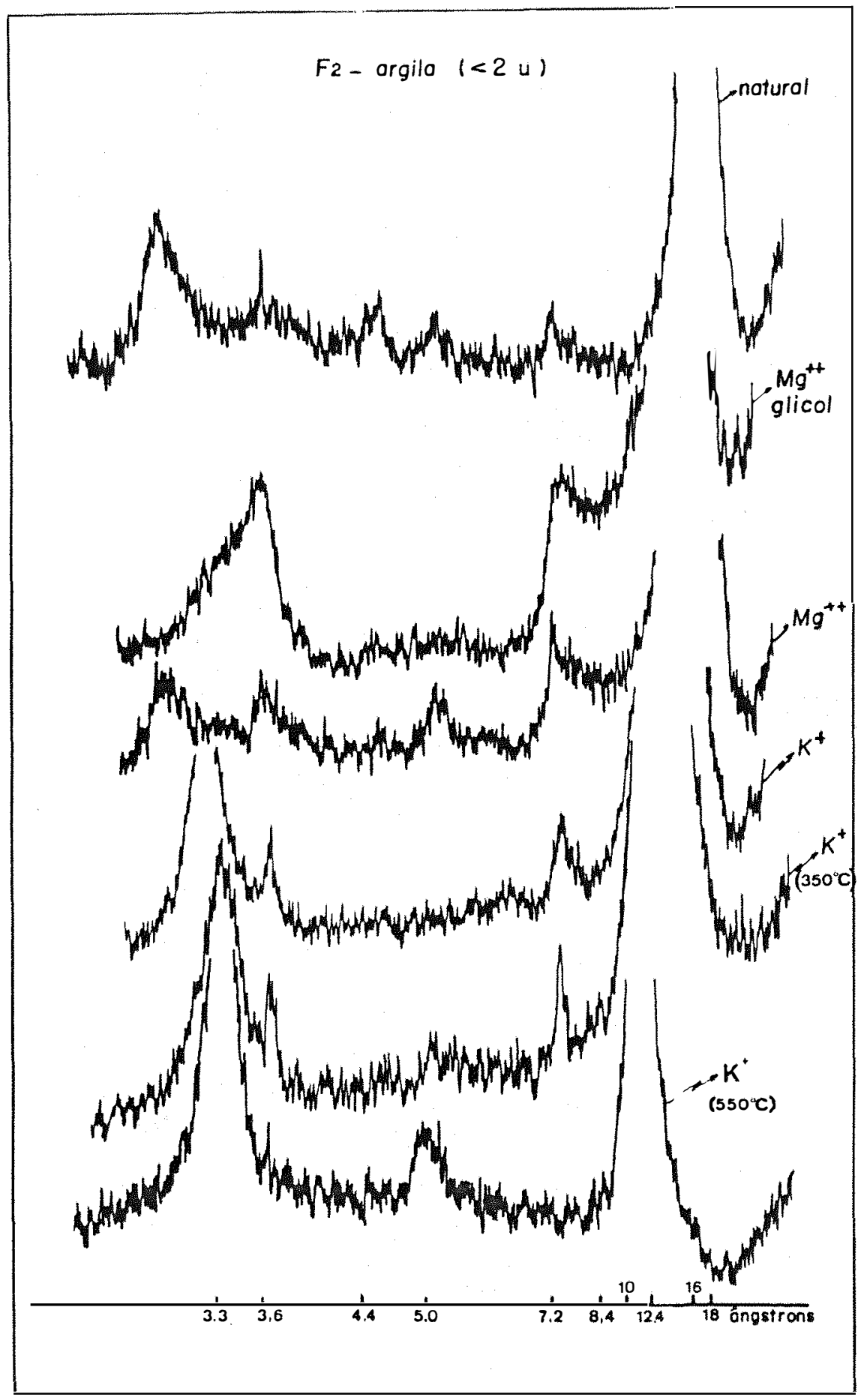

Figura 5. Difratogramas de raios- $\chi$ da fração argila $(<2 \mu)$ da segunda fase de alteração $\left(F_{2}\right)$, obtidos em equipamento Phillips operando a 35 $\mathrm{KV}$ e 20mA, com radiação $\mathrm{K} \alpha 1$ do $\mathrm{Cu}$ e filtro de níquel. Natural-saturação natural; $\mathrm{Mg}^{++}$-glicol-saturada com magnésio e glicolada; $\mathrm{Mg}^{++}$-saturada com magnésio; $\mathrm{K}^{+}$-saturada com potássio; $\mathrm{K}^{+}-350^{\circ} \mathrm{C}$-sa turada com potássio e aquecida a $350^{\circ} \mathrm{C}: \mathrm{K}^{+}-550^{\circ} \mathrm{C}$-saturada com pó tássio e aquecida a $550^{\circ} \mathrm{C}$. 


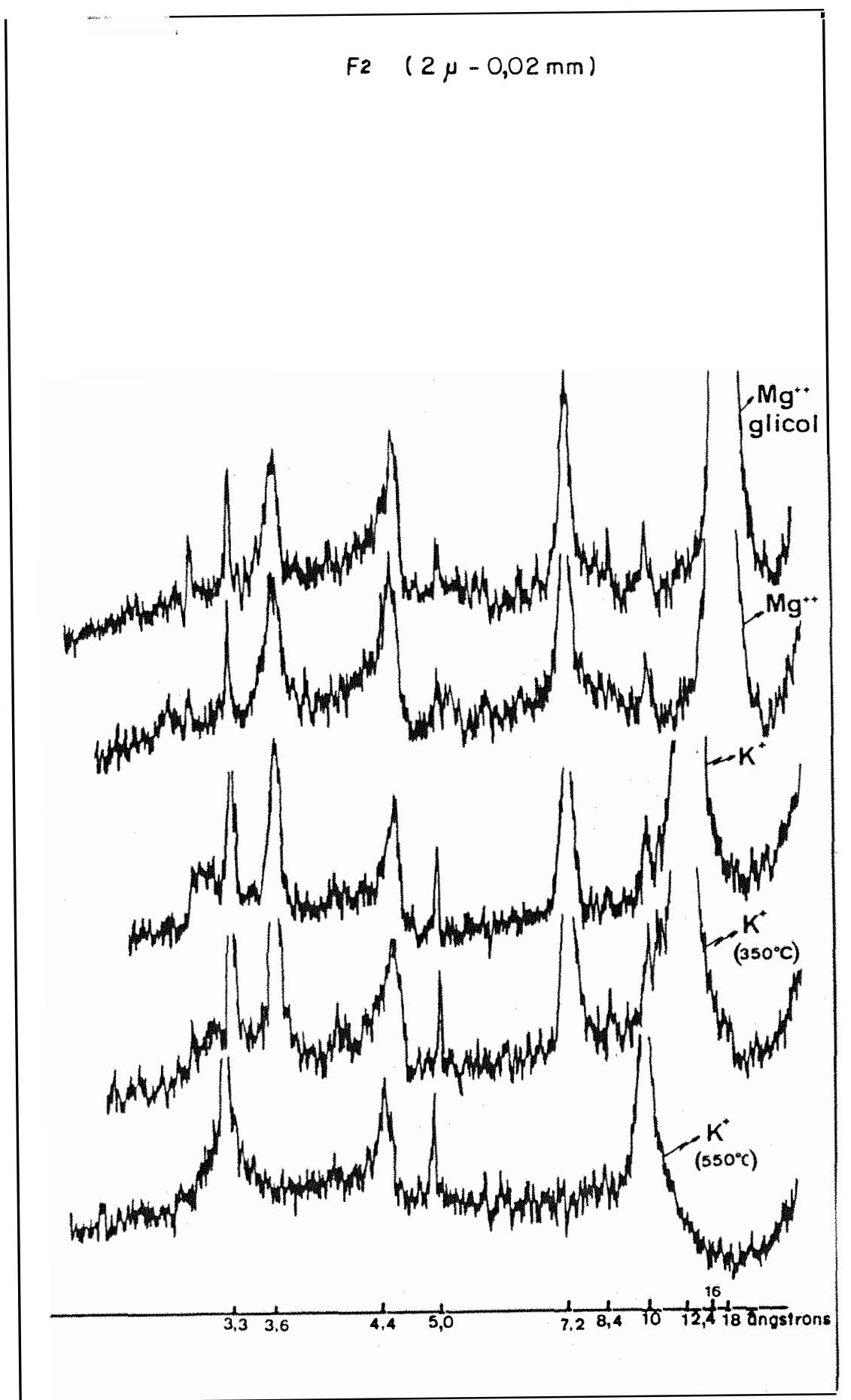

Figura 6. Difratogramas de raios-X da fração $2 \mu-0,02 n m$ da segunda fase de alteração $\left(\mathrm{F}_{2}\right)$, obtidos em equipamento Phillips, operando a $35 \mathrm{KV}$ e $20 \mathrm{~mA}$, com radiação $\mathrm{Kal}$ do $\mathrm{Cu}$, e filtro de níquel. $\mathrm{Mg}^{++}$- glicolsaturada com magnésio e glicolada; $\mathrm{Mg}^{++}$-saturada com magnésio; $\mathrm{K}^{+}$-saturada com potássio; $\mathrm{K}^{+}-350^{\circ} \mathrm{C}$-saturada com potássio e aquecí da a $350^{\circ} \mathrm{C} ; \mathrm{K}^{+}-550^{\circ} \mathrm{C}$-saturada com potássio e aquecida a $550^{\circ} \mathrm{C}$. 


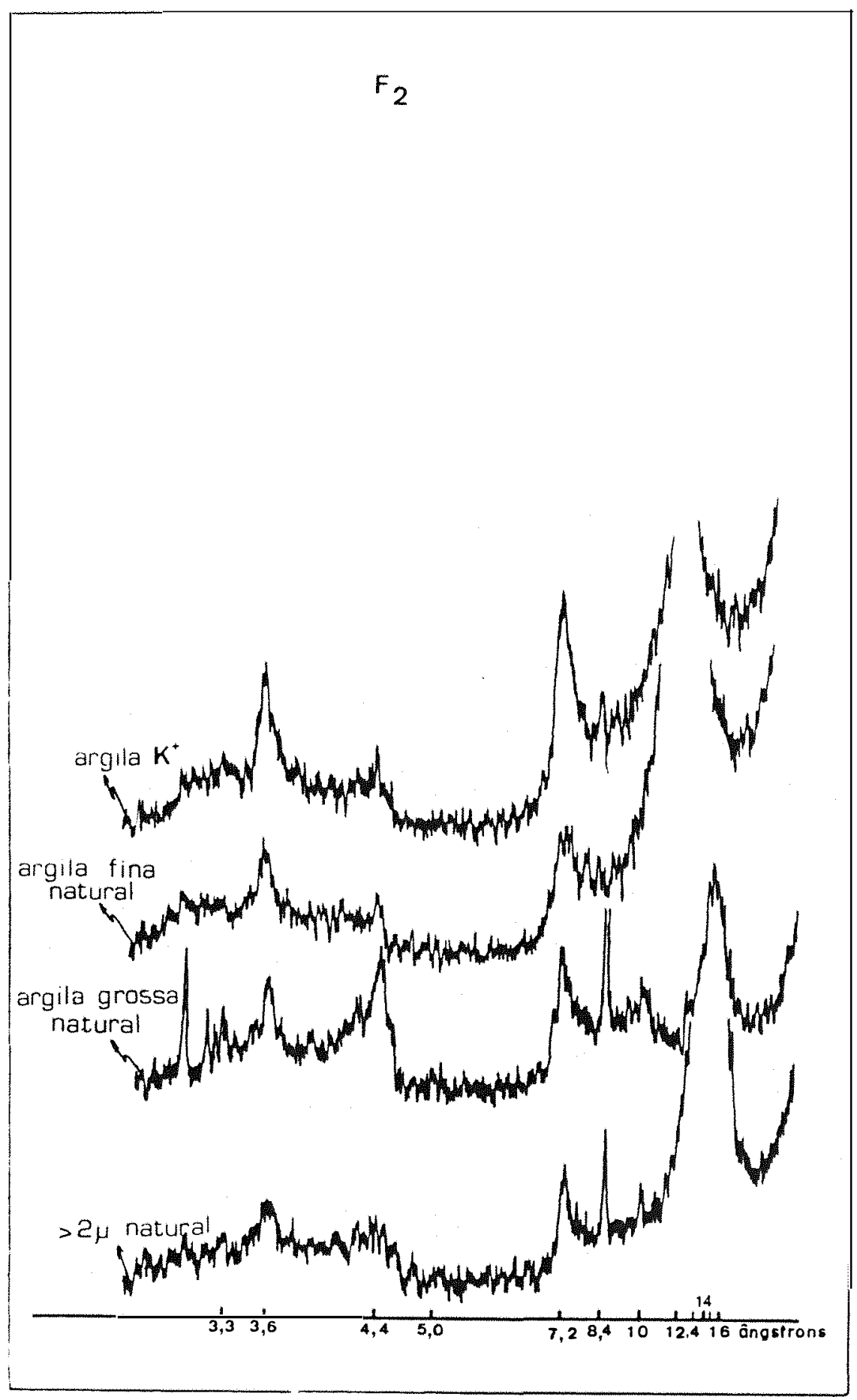

Figura 7. Difratogramas de raios $-X$ das amostras: argila- $K^{+}$, argila fina natural, argila grossa natural e fração $>2 \mu$ natural, da segunda fa se de alteração $\left(F_{2}\right)$, obtidos em equipamento Phillips operando a $35 \mathrm{KV}$ e $20 \mathrm{~mA}$, com radiação $\mathrm{Kal}$ do $\mathrm{Cu}$ e filtro de níquel. $\mathrm{K}^{+}$-satu rada com potássio. 


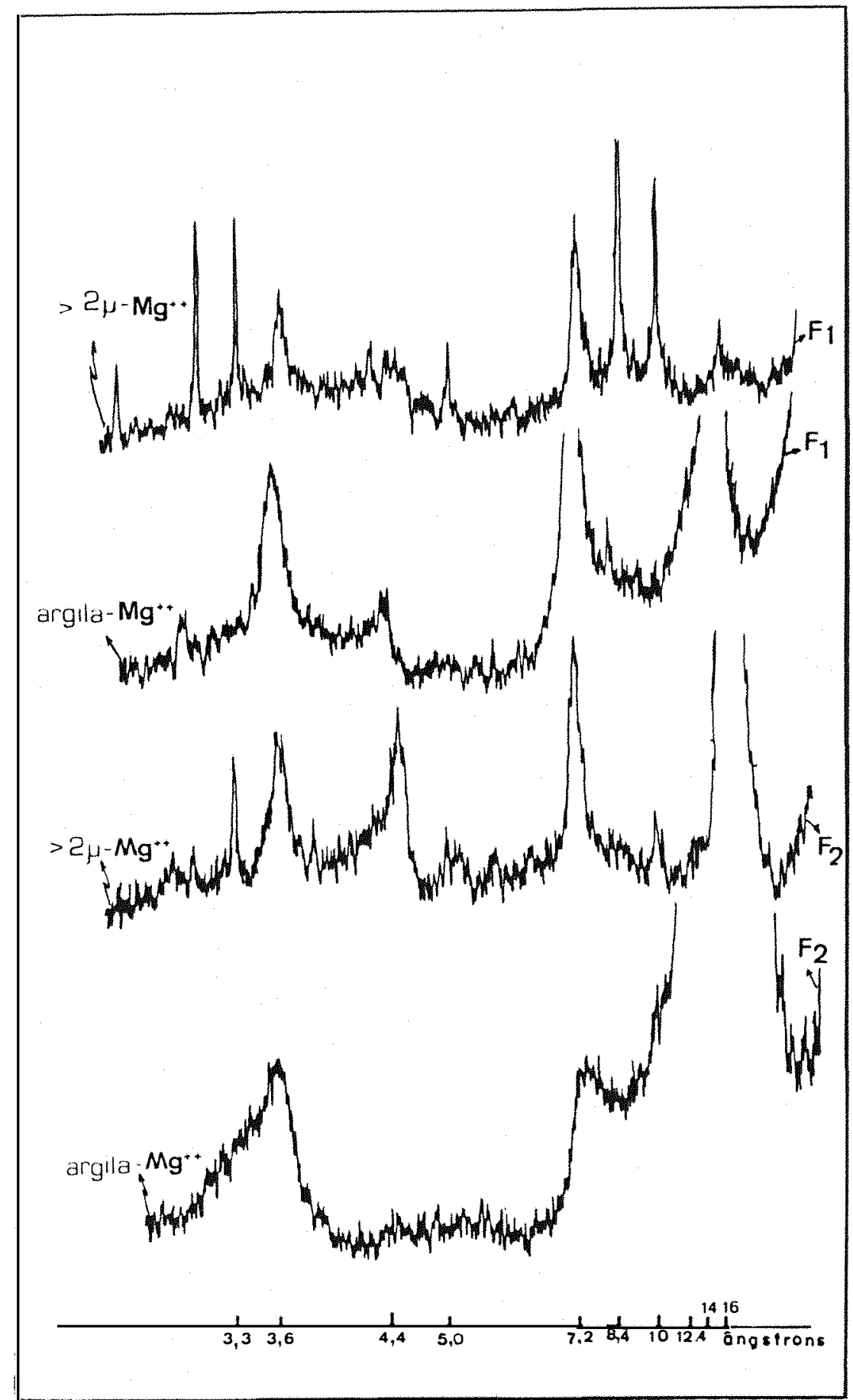

Figura 8. Difratogramas de raios-X das amostras Mg-saturadas (argila e $>2 \mu$ ) das fases $F_{1}$ e $F_{2}$ obtidos em equipamento Phillips, operando a 35 $\mathrm{KV}$ e $20 \mathrm{~mA}$, com radiação $\mathrm{K} \alpha 1$ do $\mathrm{Cu}$, e filtro de níquel. $\mathrm{Mg}^{++}$-satú rada com magnésio. 
talina desse mineral, e a quantidade liberada na solução não seria suficiente para promover a substituição do $\mathrm{K}^{+}$adsorvido. Além disso, na condição de ambiente mal drenado o fluxo de mas sa é pequeno, diminuído ainda pela pequena permeabilidade cau sada pela formação de minerais de argila 2:1 nas superfícies de alteração, de modo que as possíveis trocas entre aqueles íons seriam, possivelmente, apenas por difusão iônica, o que difí cultaria ainda mais a substituição, mantendo a argila natura mente saturada com potássio.

Com a progressão da meteorização, o anfibólio forne ceria quantidades de magnésio suficiente para a troca do $\mathrm{K}^{+}$pe $10 \mathrm{Mg}^{2+}$, ou então a quantidade de montmorilonita naturalmente saturada com magnésio formada subsequentemente na intemperiza ção, teria diluído sobremaneira a concentração de montmorilonita $-\mathrm{K}^{+}$saturada proveniente da alteração de feldspato, não sendo possível a sua detecção através da difração de raios-X.

A separação da argila natural da $F_{2}$ em fração grossa e fina demonstram que a segunda hipótese é a mais provável, pois que a fração fina revela a presença de argila com espaça mento de $12,4 \AA$, enquanto que a fração grossa apresenta minerais com espaçamento de $16 \AA$ (Figura 7).

Pelo exposto, poder-se-ia estabelecer as seguintes sequências de alteração:

feldspato $\longrightarrow$ caulinita $\longrightarrow$ montmorilonita (A1), admitindo-se uma ressilicatização da caulinita, compatível com as condições de drenagem; 


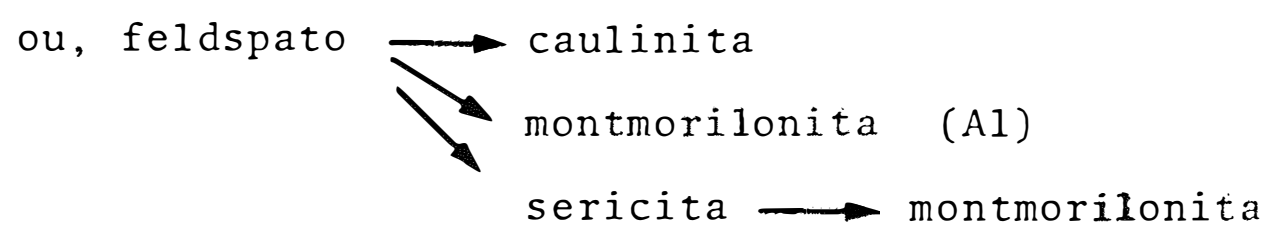

pela alteração concomitante do mineral primário dos tres minerais neogênicos;

$$
\text { anfibólio } \longrightarrow \text { nontronita }
$$

pela alteração subsequente;

$$
\begin{aligned}
& \text { e ainda, } \\
& \text { nontronita ou montmorilonita }(\mathrm{Al}) \longrightarrow \text { vermiculita }
\end{aligned}
$$

A dedução de que a origem da montmorilonita (Al) é proveniente do feldspato e a nontronita do anfibólio baseia-se também na diferença do comportamento desses minerais frente a glicolação, onde encontramos valores de $18 \AA$ para montmorilonita, magnésio saturada-glicolada e $16 \AA$ para a nontronita mag nésio saturada-glicolada.

\subsection{Fotografias das Secções Delgadas}

A fotografia 1 da secção delgada da rocha fresca mos tra a sua estrutura, a morfologia e a disposição dos minerais constituintes. Os anfibólios apresentam-se ainda inalterados, enquanto que o plagioclásio já se encontra em início de climatização.

Na primeira fase de alteração a fotografia 2 mostra a alteração total do plagioclásio, permanecendo ainda intacta parte do anfibólio. Contudo, a estrutura da rocha é conserva da. 


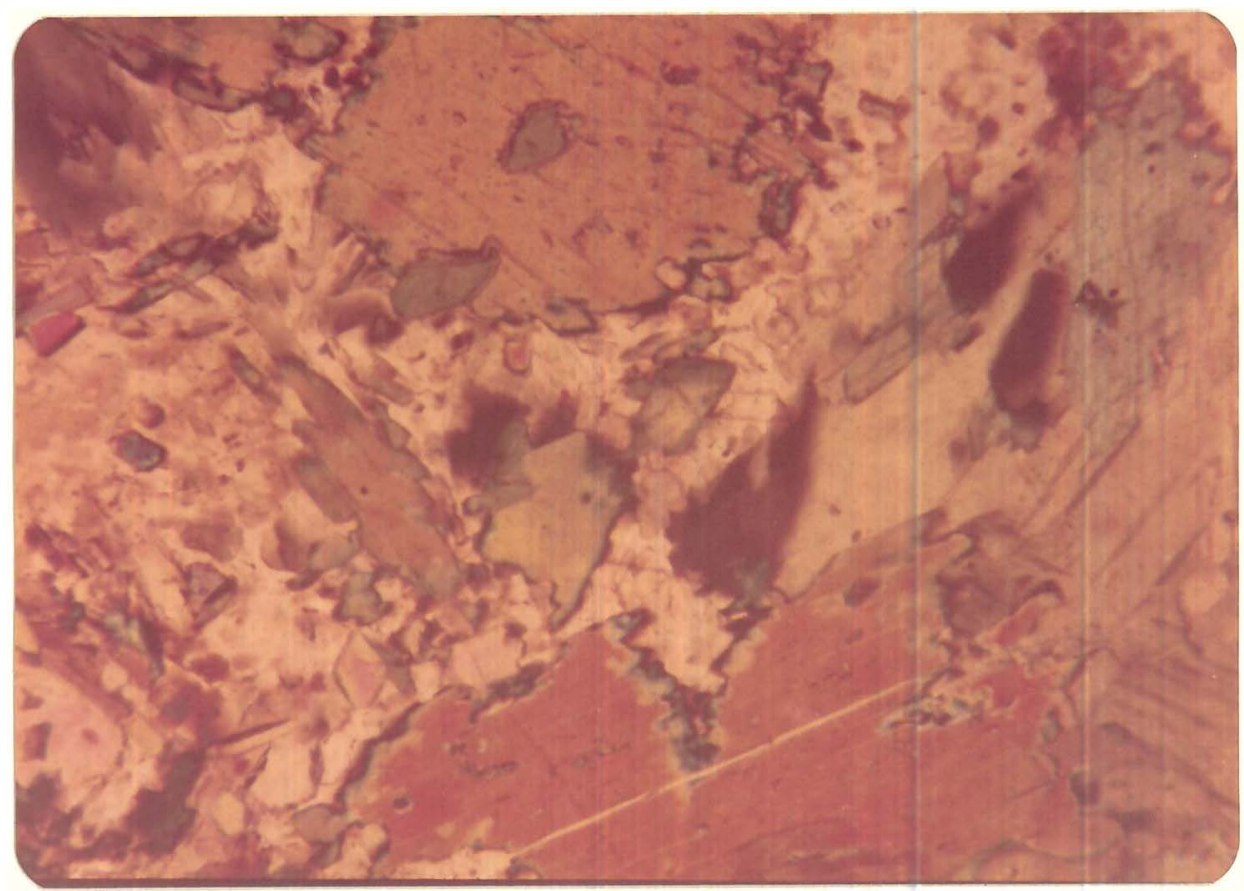

Foto $n^{\circ}$ 1: Secção delgada da rocha fresca em microscópio de polarização com nicóis cruzados. Aumento 116X.

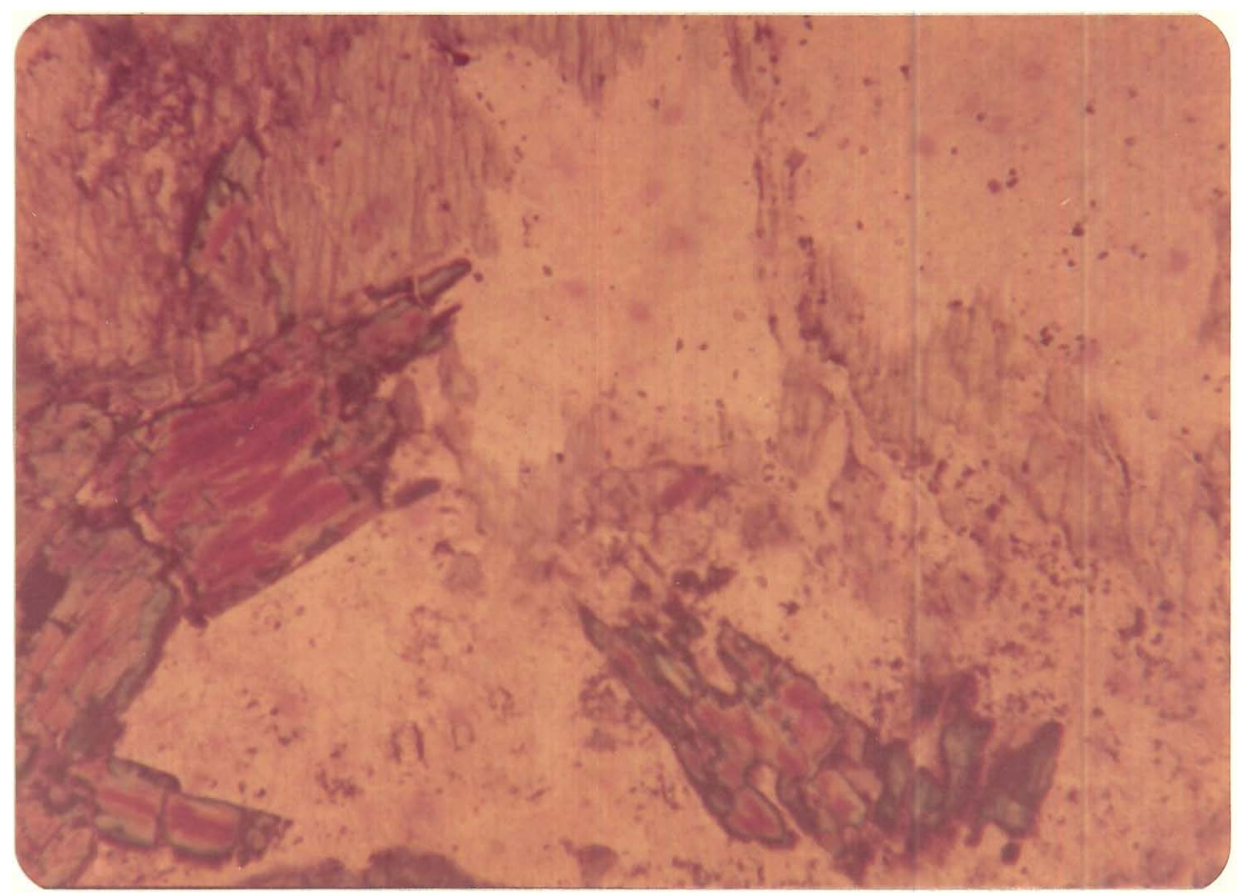

Foto $n^{\circ}$ 2: Secção delgada da prımeıra fase de alteração ( $\left.F_{1}\right)$, em microscópio de polarização com nicóis cruzados. Aumento $116 x$. 
.47 .

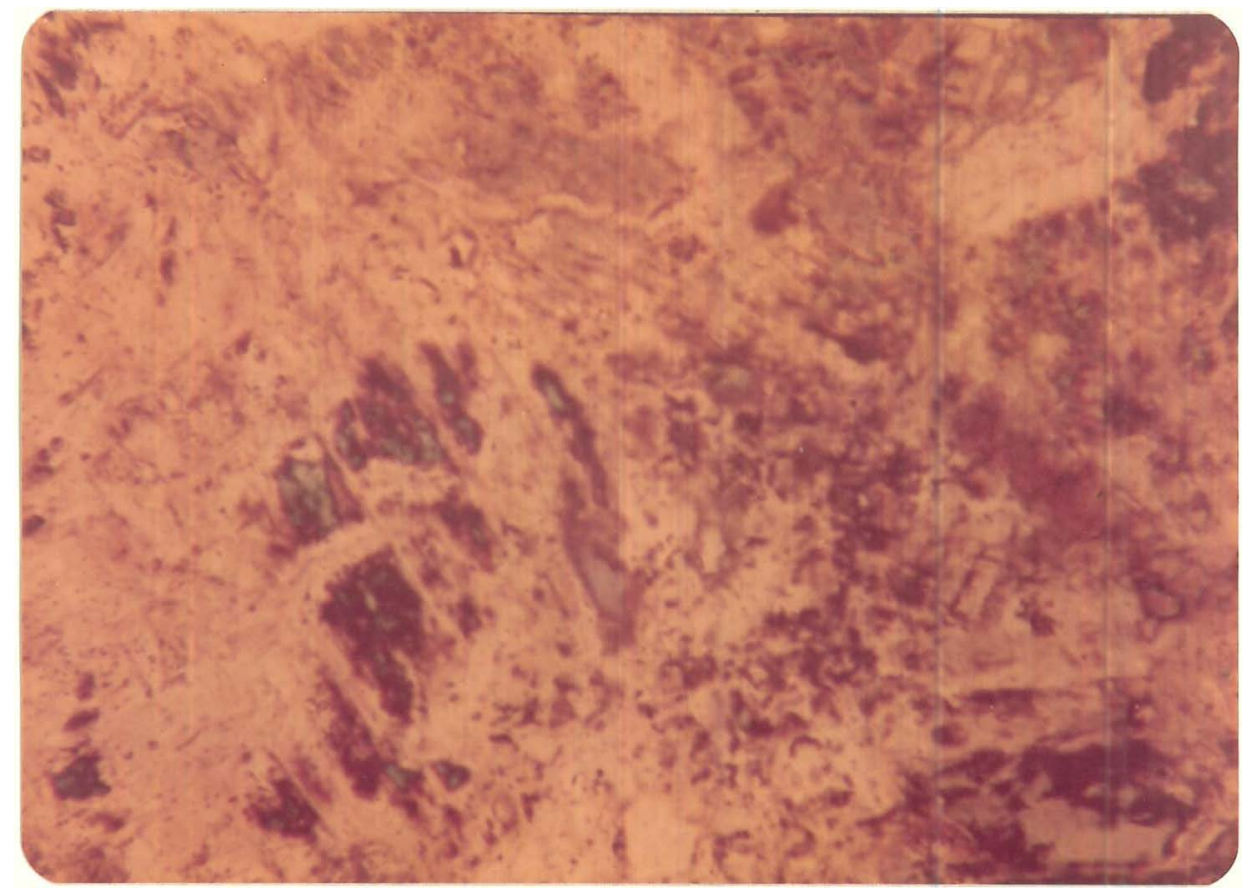

Foto $n^{\circ}$ 3: Secção delgada da segunda fase de alteração $\left(F_{2}\right)$, em microscópio de polarização com nicóis cruzados. Aumento de $116 X$. 
Em sequência, a fotografia 3 , da segunda fase de a $\underline{-}$ teração, revela a destruição total dos minerais primários, man tendo ainda a estrutura da rocha original, mostrando a ausên cia de movimentação da capa alterada, após sua formação.

Os resultados dessas análises atestam também a validade do critério de escolha das fases de alteração baseado em densidade, coesão e cor citado por MELFI \& LEVI (1971).

4.10. Fotografias de Fragmentos das Fases de Alteração com os Reativos Alizarina e Ferrocianeto de Potássio

Através da reação com a alizarina podemos observar melhor nas fotografias 5 e 8 a maior concentração da nontroni ta nas regiōes próximas ao anfibólio. Pela ausência de movimen tação posterior dos produtos de alteração, pode-se atribuir a origem da nontronita a partir do anfibólio, e da caolinita a partir do plagioclásio.

Em concordância com as afirmações anteriores, as rea ções com o ferrocianeto de potássio (Fotos 6 e 9) também mos tram maiores concentrações de nontronita próximas aos anfibólios, sugerindo mais uma vez a origem da nontronita diretamen te a partir do anfibólio.

4.11. Fotografia da Vermiculita Expandida

Como foi visto, a vermiculita aparece apenas nas fra ções superiores a 2 micra, e a respeito de sua gênese, na alte ração ora estudada, somente é possível estabelecer hipóteses a 


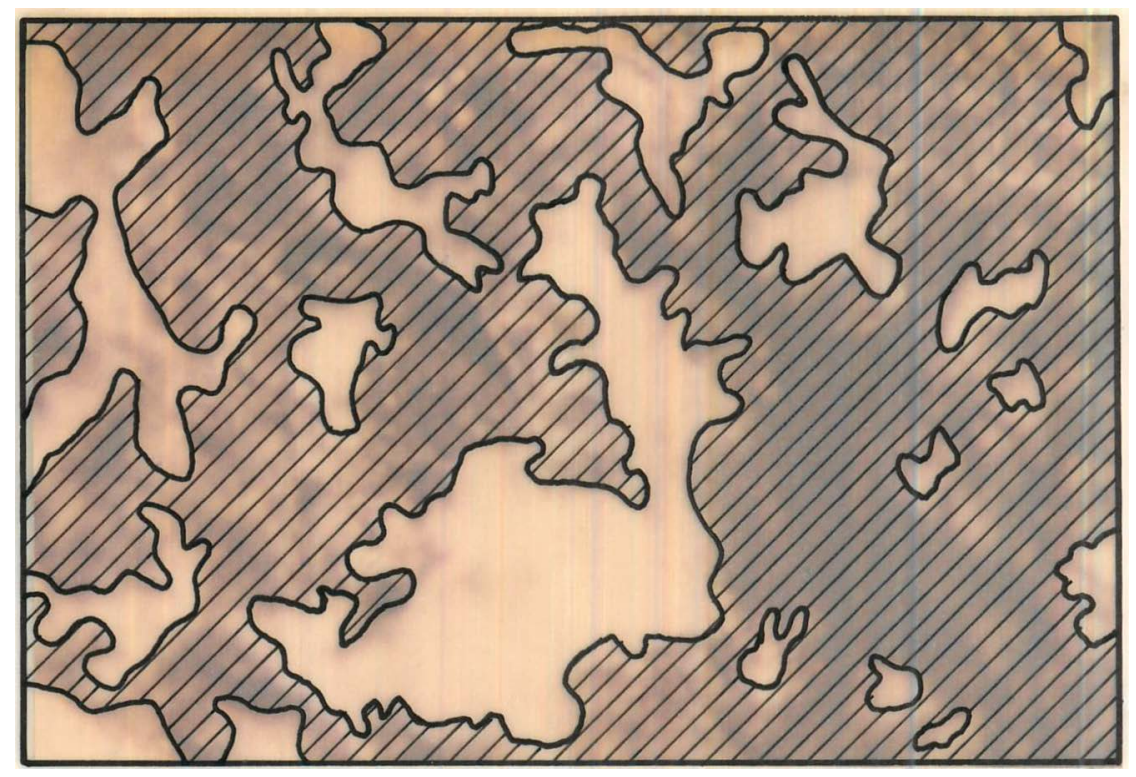

.49.

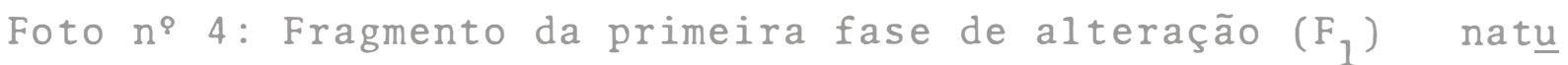
ral. Aumento 40X.
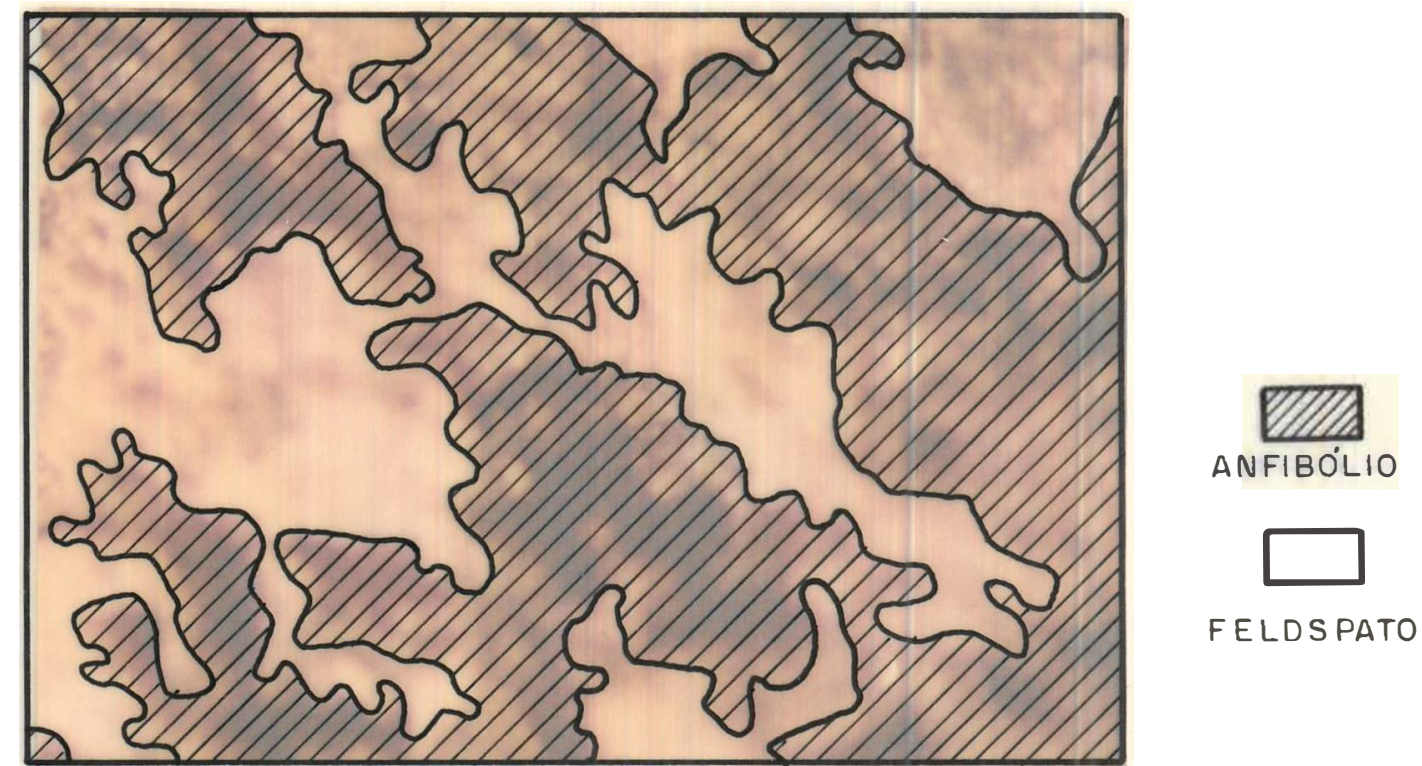

Foto n: 5: Fragmento da primeira fase de alteração $\left(F_{1}\right)$ com o. reativo alizarina. Aumento $40 \mathrm{x}$.

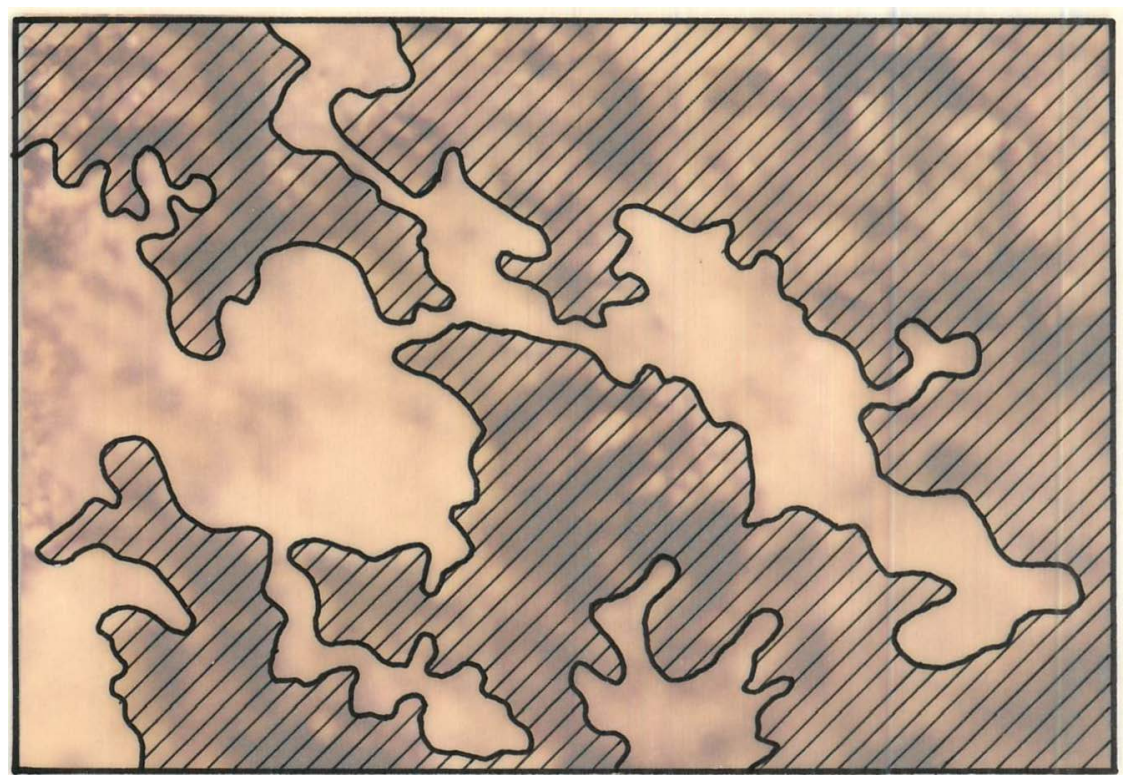

Foto $n^{\circ}$ 6: Fragmento da primeira fase de alteração ( $F_{1}$ ) com o reativo ferrocianeto de potássio. Aumento $40 \mathrm{X}$. 


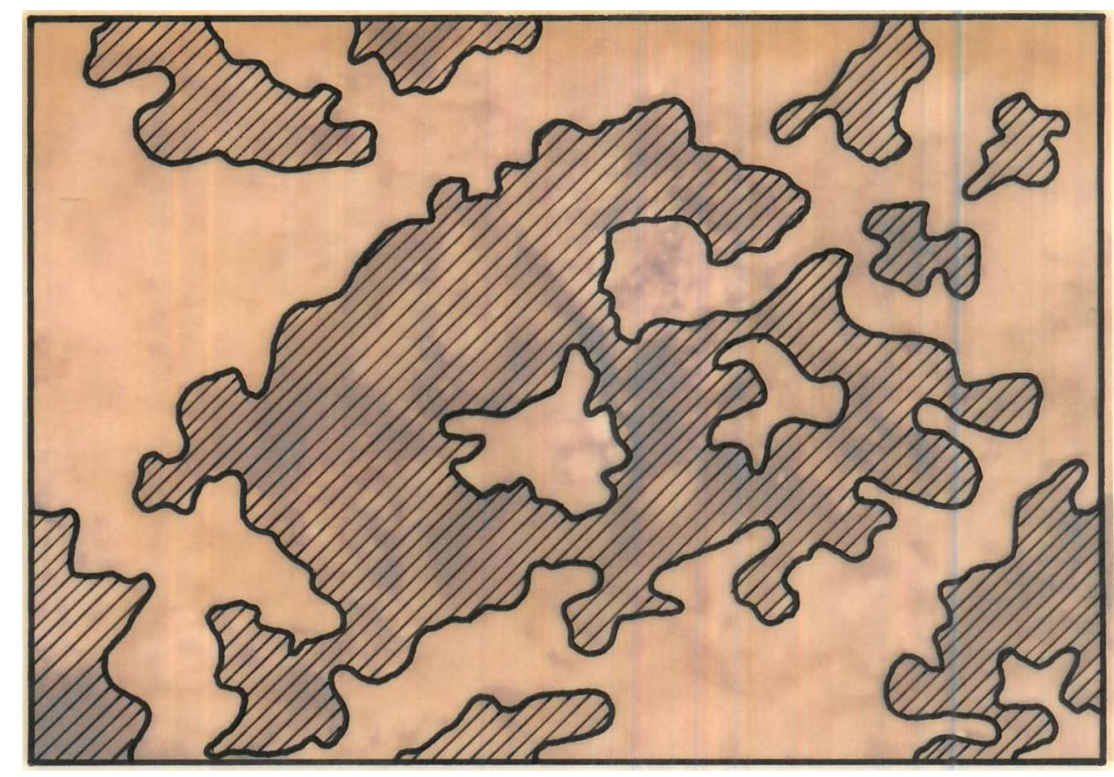

Foto n: 7: Fragmento da segunda fase de alteração (F2) natural. Aumento de $40 \mathrm{X}$.
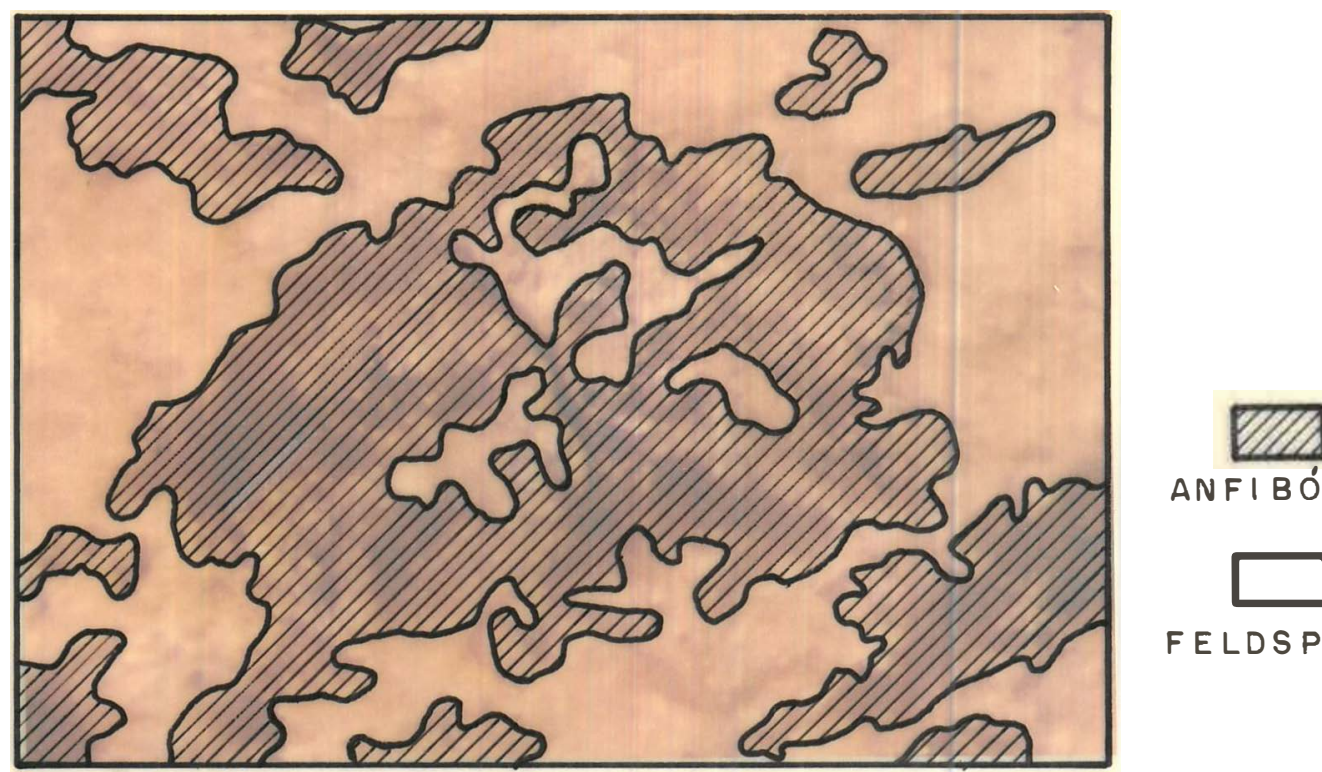

FELDSPATO

Foto $n^{8}$ 8: Fragmento da segunda fase de alteração $\left(\mathrm{F}_{2}\right)$ com o reativo alizarina. Aumento $40 \mathrm{x}$.

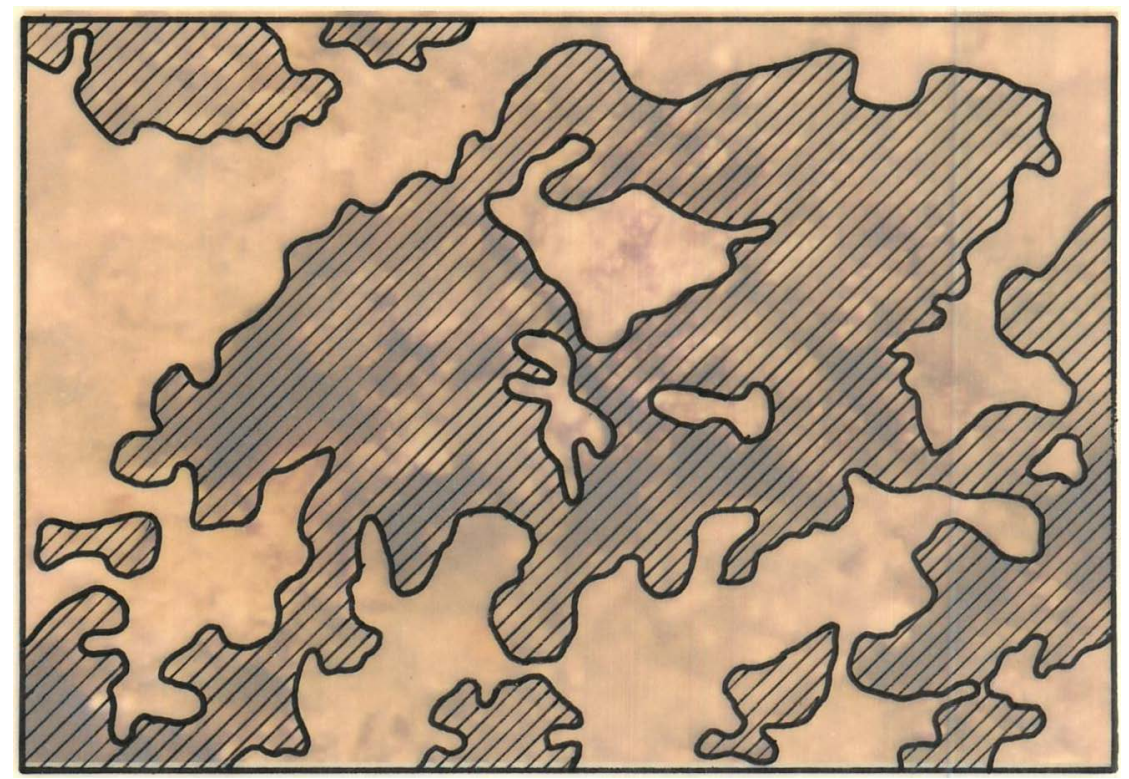

Foto $n^{\circ}$ 9: Fragmento da segunda fase de alteração $\left(F_{2}\right)$ com o reativo ferrocianeto de potássio. Aumento $40 \mathrm{X}$. 
partir dos resultados encontrados, cujas confirmaçōes merecem estudos mais aprofundados e específicos, à parte. Tanto a ori gem hidrotermal direta (SHIMANE, 1969), como a partir de uma estrutura cloritosa (GLABAUGH \& BARNES, 1957; MONCHOUX et alii, 1963), ou ainda pelas alteraçōes da biotira e da flogopi ta (BETEKHTINE, 1968) ou pelo processo de migmatização (MON CHOUX, 1961) não permitem explicar a gênese da vermiculita na alteração do anfibolito estudado, uma vez que os referidos pro cessos e os minerais relatados não se fazem presentes na situa ção.

As possíveis hipóteses explicativas da origem da ver miculita seriam:

- a partir do mineral primário hornblenda, como admi te MILLOT (1964);

- a partir da montmorilonita, nontronita ou serici ta por um crescimento de seus cristais, de modo semelhante ao observado por GRIM \& JOHNS (1954);

- pela alteração mica (sericita) $\longrightarrow$ vermiculita, co mo preconizado por JACKSON et alii (1952) para a fração argila em solos.

Contudo, devido às dimensōes atingidas pela vermiculita (Figura 10) em qualquer um dos casos previstos para a sua gênese, deve ocorrer um crescimento dosseus cristais pelo ar ranjamento contínuo e ordenado dos constituintes da solução so bre os núcleos de cristalização como proposto por GASTUCHE et alii (1962). A sua manutenção na camada mais alterada $\left(F_{2}\right)$ é favorecida pelo enriquecimento da solução em magnésio, prove niente da alteração da hornblenda como afirma NOVIKOFF (1974). 


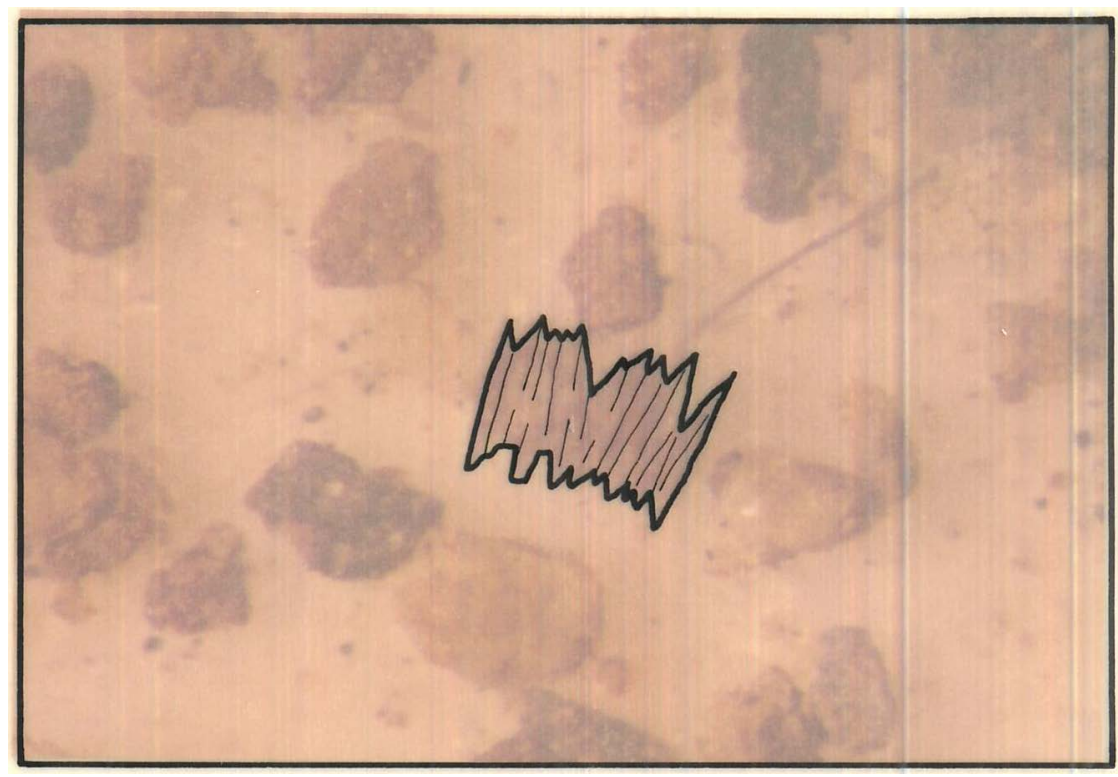

VERMICULITA

Foto n: 10: Vermiculita expandida por aquecimento räpido a $900^{\circ} \mathrm{C}$ da fração 1 a $2 \mathrm{~mm}$ da segunda fase de altera ção $\left(\mathrm{F}_{2}\right)$. Aumento $10 \mathrm{X}$. 
.53

Pelo exposto acima, a afirmação de BASSET (1963), de que todas as vermiculitas de grande porte provém da alteração superficial de biotita e flogopita, não é aqui confirmada, vis to que esses minerais não estão presentes na alteração ora estudada.

A presença da vermiculita na fração acima de $0,125 \mathrm{~mm}$ pode ser observada na fotografia 10 . 
5. CONCLUSOES

A alteração dos anfibolitos embora ocorrida sob con dições de clima tropical úmido, a particularidade geológica de material encaixado ou confinado conduz a um processo de in temperismo também particular. Assim é, que as precárias condi ções de drenagem e, consequentemente, de lixiviação, propiciam uma relativamente pequena remoção de bases e sílica em comparação às condições normais, razão pela qual a montmorilonita assume papel primordial dentre os minerais neogênicos. A reali mentação constante de bases e sílica proveniente dos minerais primários em alteração mantém as condições físico-químicas deais para a formação e manutenção desse mineral nas primeiras 
fases de alteração, auxiliada ainda pelo enriquecimento em ba ses e sílica carreadas pela água de percolação, à medida que esta se aprofunda no manto de intemperismo.

Sob condições de drenagem imperfeita o plagioclásio (andesina) altera-se primeiramente ao anfibólio (hornblenda), produzindo montmorilonita e caulinita; a montmorilonita proveniente do anfibólio tem constituição diferente da origināria do plagioclásio, com substituição isomorfa do alumínio por fer ro na camada octaédrica do mineral, caracterizada como uma non tronita.

São possíveis as seguintes sequências de alterações minerais:

a) Alteração do anfibólio

hornblenda $\longrightarrow$ actinolita (anfibólio)

b) Alteração do plagioclásio (nontronita)

montmorilonita (A1)

caulinita

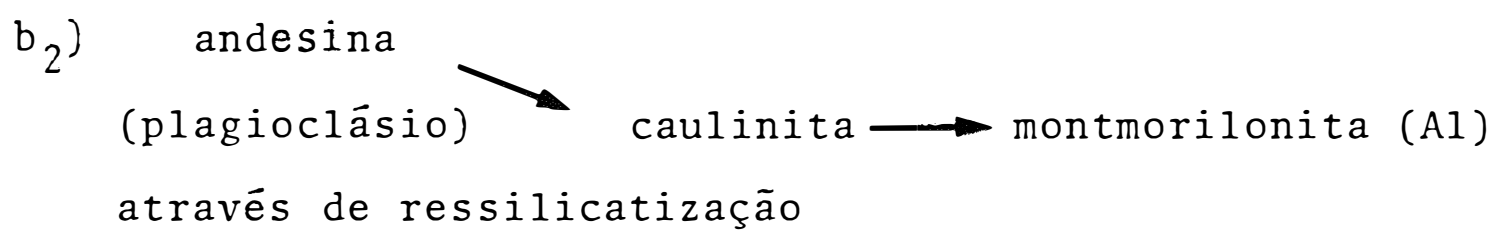

Podemos concluir também que um dos fatores que deter minam as grandes variaçōes na remoção da sílica e das bases en contradas por MONIZ et alii (1973) em alteraçōes de rochas bá 
sicas em climas semelhantes é a condição de drenagem, uma vez que neste trabalho encontramos uma remoção de sílica e bases bem inferior àquelas citadas pelo referido autor.

A alteração das rochas ferromagnesianas com a forma ção de nontronita constitui-se num processo da natureza para separação do Fe do Mn.

O meio confinado ou de pequena drenagem, mesmo sob condições de clima tropical úmido, corresponde aproximadamen te, em termos de intemperismo, à condições de clima de pequena intensidade pluviométrica, ou seja, influi no fator cinético das reações, retardando a climatização. 
The present research aimed to study the intemperiza tion of anfibolites situated on imperfect drainning conditions by analytical characterization of the fresh rock and two des crimined alteration crusts (alteration phases).

By a granulometrical analysis of the alteration: crusts it was observed a increase on clay fractions depending on the degree of intemperization. At the fresh rocks and the two alteration crusts, densities decreased with the alteration phase, presenting the following values $2.28 ; 2.09$ and 1.14 $\mathrm{g} / \mathrm{cm}^{3}$ respectively. The $\mathrm{pH}$ also decreased toward the same di rection: $8.3 ; 7.4$ and 7.0 . 
The chemical analysis of the fresh rock and clay fraction showed up that the poor drainage condition caused a small remove of basis and silica as well as an aluminium accu mulation, with formation of $2: 1$ minerals as demonstrated by $X$-rays difratograms.

The clay fraction of the first alteration phase shows predominantly montmorillonite and caulinite occurring together with mica. Otherwise in the silt fraction, vermiculi te, mica, actinolite, caulinite and quartz were the accurring minerals.

In the second alteration phase the clay fraction is basically, constituted by montmorillonite and a small amount of caulinite. In the silt fraction montmorillonite, caulinite and small proportions of actinolite and quartz were found.

The fluorescence $X$-rays analysis showed up an increa se on concentrating of $\mathrm{Ti}, \mathrm{Cr}$, and $\mathrm{Fe}$ and a loss of $\mathrm{Ca}$ and $\mathrm{Mn}$. Potassium and Si were constant for the alteration stages studied.

The tests of fresh rock thin sections by polariza tion microscopy showed the presence of hornblenda partially transformed to actinolite, and andesina partially alterated to epidot. Titanite, rare apatite and quartz were also present as acessory minerals. The sections of alteration phases showed up the absence of material movement after alteration took place.

The treatments of the alteration phase fragments with alizarin and potassium ferrocianide allow to conclude that nontronite arised from anfibolite alteration and caulinite from plagioclase. 
BASSET, W.A. 1963 - The geology of vermiculite occurenses. Clays and Clays Miner., (10 ${ }^{\text {th }}$ Nation. Conf) pp 61-69. BATES, T.F. 1962 - Halloysite and gibbsite formation.Clays and Clays Miner., ( $9^{\text {th }}$ Conf. Pergamon Press), Hawaii, pp. 315328 .

Betekhtine, A. 1965 - Manual de Mineralogie Descritive. Mir. Moscou, $731 \mathrm{p}$.

CAILlERE, S. \& S. HENIN - 1963 - Mineralogie des argiles. Mas son e Cie, $355 \mathrm{p}$. 
.60

CARVAlHO, A. ; A.G. MELFI ; I. BITTENCOURT; J.P. QUEIROZ NE TO \& P. NAKASHIMA - 1967 - Sedimentos néo-cenozóicos na á rea de Campinas-SP. In: Anais do Congresso Brasileiro de Geologia. Curitiba, Sociedade Brasileira de Geologia, p. 58-70.

ClABAUGH, S.E. \& U.E. BARNES - 1957 - Origin of Central Texas vermiculite deposits. Bul.. Geol. Soc. Amer. 68, p. 1709.

COLLIER, D. 1961 - Mise au point sur les processus de 1'altera tion des granites em pays tempérés. Ann. Agron. 12(3): 273331.

DELVIGNE, J. 1965 - Pédogenèse en zone tropicale.

Mémoires ORSTOM (15): $177 \mathrm{p}$.

ESPINDOLA, C.R. 1973 - Aspectos genéticos e taxonômicos de so los da Fazenda Experimental de São Manuel. (Tese de Doutora mento)/FCMBB. 90 p. Botucatu-SP.

FALCI, S.C. 1973 - Identificação de cutans em perfis de Latossol Roxo e Terra Roxa Estruturada. (Dissertação de Mestra do)/ESALQ. 76 p. Piracicaba-SP.

FIELDS, M. E L.D. SWINDLE - 1954 - Chemical weathering of sili cates in soil formation. New Zeland J. Sci. Thech. 36: 14054 .

GALHEGO, H.R. 1973 - Contribuição ao estudo da gênese de latos solos - fase arenosa do Município de Botucatu-SP. (Tese de Doutoramento) FCMBB . 84 p. Botucatu-SP. 
GASTUCHE, M.C. ; J.J. FRIPIAT \& C. KIMPE- 1962 - Genèse des minéraux argileux de 1 a famille du Kaolin. I - Aspect Co1 loidal. Genèse et sinthèse des argiles. In: Colloques Inter nationaux du Centre National de la Kecherche Scientifigue. n: 105. Paris. p. 57-81.

GLORIA, N. da ; R.A. CATANI \& T. MATUO - 1965 - Determinação da capacidade de troca de cátions do solo pelo método do EDTA. Revta. Agric., Piracicaba, 40: 193-198.

GOMES, C.B. 1962 - Contribuição ao conhecimento dos anfiboli tos da região de Jaraguā-SP : Bo1 Soc. Bras. Geo. 11(1):5758 .

GOLDICH, S.S. 1938 - A study in rock Weathering. Jour. Geol. 46: $17-58$.

GRIM, R.E. \& W.D. JOHNS - 1954 - Clays minerals investigations of sedments in the northern gulf of Mexico. Clays and Clays Minerals $\left(2^{\text {th }}\right.$ Nat. Conf. 1953), pp. 81-103.

JACKSON, M.L. ; S.A. TYLER ; A.L.WILLIS ; G.A. BOURBEAU \& R.P. PENNINGTON - 1948 - Weathering sequence of clay - size minerals in soils and sedments. Journ. Phys. Co11. Col1. Chem., 53: 1237-1260.

KARPOFF, A.M. 1973 - Geochimie de deux toposéquences de sols tropicaux duthad. These in: NOVIKOFF, A. 1974. L'alteration des roches dans le masses du Chailu (Republique Populaire du Congo). Formation e évolution des argiles en zone ferralitique. (These Der. Sc. Nat.)/L'Unniversité Louis Pas teur de Strasbourg. $308 \mathrm{p}$. 
KOLTHOFF, M.I. \& E.B. SANDELL - 1952 - Testbook of Quantitati ve Inorganic Analysis. Thrid edition. $515 \mathrm{p}$.

KRAUSKOPF, K.B. 1972 - Introdução à geoquímica. Ed. USP. Vol. I. 244 p. (Trad. de LANDO, M. e P.S.C. BOGUS) .

LEVI, F. \& A.J. MELFI - 1972 - Geochimical and mineralogical studies on the first stages of weathering of basic and rela ted rocks. Part II - Geochimical study. Revista Bras. de Geociências. 2: 1-7.

LOSCHE, C.K. ; R.J. MCCRACKEN \& C.B. DAVEY - 1970 - Soils of steeply sloping landscapes in the Southern Appalachian Moun tains. Proc. Soil Sci. Soc. Am., Madison, 34(3): 473-478.

MAIGNIEN, R. 1961 - Le passage des sols ferrugineux tropicaux aux sols ferralitiques dans les regions sud ouest du séne gal. Sols. Afr., Paris, 6(2): 113-72.

MELFI, A.J. \& F. LEVI - 1971 - Geochimical and Mineralogical study on the first stagies of weathering of basics and rela ted rockes. Part I. Mineralogical study. Revista Bras. Geo ciências, $\underline{2}$ : 22-8.

MENDES, A.C.T. 1972 - Identificação das argilas do solo por di fração de raio-X. Piracicaba, Depto. de Solos e Geologia da ESALQ. $60 \mathrm{p}$. (mimeografado).

MENDES, A.C.T. ; S.C. FALCI \& J.L.I. DEMATTE. Secções delgadas de solo: método de impregnação. Anais' Esc. Sup.Agric. "Luiz de Queiroz", Piracicaba, 30: 35-48.

MILlOT, G. 1964 - Geologia des argiles. Masson \& Cie, Paris. $499 \mathrm{p}$. 
MITCHELL, W.A. 1955 - A review of the mineralogy of Scottish soil clays. J. Soil Sci., 5: 167-172.

MONCHOUX, P. 1961 - Etudes mineralogiques dans le massif de la Bessenoits (Aveyron). Bull. Soc. Histo. Nat., Toulouse, 96 , $\underline{3}$ et 4 : $299-336$.

MONIZ, A.C. \& A. CARVALHO - 1973 - Estudo mineralógico dos so los derivados do arenito Bauru e rochas básicas da região noroeste do Estado de São Paulo. Bragantia, 32: 309-335.

NOVIKOFF, A. 1974 - L'altération des roches dans le masses du Chailu (Republique Populaire du Congo). Formation e évolution des argiles en zone ferralitique.(These Der. Sc. Nat.) L'Unniversité Louis Pasteur de Strasbourg. 308 p. PAIVA NETTO, J.E. de \& A.A. PACCOLA - 1973 - Um novo teste quí mico para identificação dos minerais de argila do tipo de rede 2:1. In: Anais do XIV Congresso Brasileiro de Ciência do Solo. Santa Maria, RS. 276-284.

PRECOT, A. ; M.C. GASTUCHE ; J. DELVIGNE,; L. VIELVOYE \& J.J. FRIPIAT - 1962 - L'alteration des roches et la formation de sols au Kinu. INEAC série scientifique (97).. Louvain. QUEIROZ NETO, J.P. 1969 - Interpretação dos solos da Serra de Santana para fins de classificação. (Tese de Doutoramento)/ ESALQ. 135 p. Piracicaba, SP.

RADWANSKI, S.A. \& C.D. OLLIER - 1959 - A study of an East Afri can Catena. J. Soil Sci., 10(2): 149-168, Oxford. SHAW, D.M. 1954 - Os elementos traços nas rochas pelíticas. Bu11. Geo1. Soc. Amer., 65, 1151-1182. 
.64.

SIEGNEMARTIN, C.L. 1974 - Algumas aplicações da Fluorescência de raios-X por excitação radioisotópica em rochas e minérios. (Dissertação de Mestrado)/Instituto de Geociências da USP, São Paulo, 84 p.

SMITH, J. 1957 - A mineralogical study of weathering and soil formation from olivine basalt in Northern Irland. J. Soil Sci., $\underline{8}: 225-239$.

TEIXEIRA, A.J.S. 1962 - Os solos da Guiné Portuguesa. Carta Ge ral, características, formação e utilização. Junta de Inves tigação do U1tramar, 397 p. (mimeografado). 